IFN Working Paper No. 820, 2010

Firm Growth, Institutions and Structural Transformation

Magnus Henrekson and Dan Johansson 


\title{
Firm Growth, Institutions and Structural Transformation*
}

\author{
Magnus Henrekson ${ }^{\dagger}$ and Dan Johansson*
}

April 27, 2010

Abstract: See non-technical summary overleaf.

Keywords: Entrepreneurship; Firm growth; Gazelles; High-growth firms; High-impact firms; Institutions; Job creation; Rapidly growing firms.

JEL Codes: D21; L25; M13; O10; O40.

\footnotetext{
* We are grateful for useful comments and suggestions from Selva Baziki and Michael Fritsch. Henrekson acknowledges financial support from the Jan Wallander and Tom Hedelius Foundation and from the Gustaf Douglas Research Program on Entrepreneurship at the Research Institute of Industrial Economics (IFN), Stockholm. Johansson acknowledges financial support from Sparbanksstiftelsen Alfa. ${ }^{\dagger}$ Corresponding author. Research Institute of Industrial Economics (IFN), P.O. Box 55665, SE-102 15 Stockholm, Sweden. Ph: +46-8-665 45 02. E-mail: Magnus.Henrekson@ifn.se. Personal website: www.ifn.se/mh.

* The Ratio Institute, P.O. Box 3203, SE-103 64 Stockholm, Sweden. E-mail: dan.johansson@ ratio.se. Personal website: www.ratio.se/eng/johansson
} 


\section{Non-technical summary}

This essay argues that the economic contribution of certain firms - be they small, young or rapidly growing - has to be understood in a broader context of creative destruction. Growth of some firms requires contraction and exit of some other firms to free up resources that can be reallocated to expanding firms. Entry and expansion are flip sides to exit and contraction and the process through which the factors of production are put into different use defines structural transformation. We analyze institutions and policies conducive to structural transformation, in particular the expansion of high-growth firms (HGFs), since they have empirically been shown to contribute disproportionately to economic development.

Firm growth is viewed as resulting from the continuous discovery and use of productive knowledge. Rapid firm growth requires a set of economic actors with complementary competencies that work together to identify and commercialize novel business ideas. The institutional framework determines the incentives for these individuals to acquire and utilize knowledge. We identify a number of institutions that encourage the creation of HGFs and promote structural transformation. In particular, our analysis points to the key roles played by tax structures, labor market regulation, and the contestability of service markets. Even in advanced economies, there is a large untapped economic potential which can be unleashed by institutional changes, such as the opening up of closed markets for entrepreneurial competition. However, there is no "quick-fix" that will boost the frequency of HGFs and structural transformation. Our analysis suggests that policymakers need to adopt a broad approach and implement a wide array of complementary institutional reforms to increase the prevalence of HGFs and to facilitate structural transformation. 


\section{Introduction}

For a long time, large firms were considered to create new employment and economic growth, mainly due to economies of scale in production as well as in research and development (e.g. Schumpeter, 1942; Gailbraith, 1956, 1967). This conventional wisdom was challenged by Birch (1979) who in an empirical investigation claimed small firms to be the main job generators. Birch's results and his conclusions have been questioned and sparked up a debate; see Kirchhoff and Greene (1998) for a review of the discussion. Van Praag and Versloot (2008) summarize the empirical evidence on job creation by small firms, and conclude (p. 135) that it is an unambiguous result that small firms create more jobs on net than large firms, even when the methodology suggested by the critics is applied. Subsequent research shows that a fairly small number of highgrowth firms (HGFs for short) — on average smaller and younger than other firmscontribute the bulk of net employment; see Henrekson and Johansson (2010) for a survey.

This essay has its starting point in a generally overlooked part of the critique that certain firms; may they be small, young or rapidly growing, are of particular importance for job creation and economic growth. This critique asserts that growth has to be understood in a broader perspective entailing considerable churning and restructuring (e.g. Haltiwanger and Krizan, 1999). ${ }^{1}$ In fact, rapid growth of some firms implies that they attract factors of production from other firms. Growth therefore requires contraction and exit of some firms to free up resources that can be reallocated to expanding firms. Entry and expansion are flip sides to exit and contraction. The process through which the factors of production are put into different use defines structural transformation.

It may therefore be misleading to simply focus on a particular piece of this process and claim that it alone contributes a disproportionately large share towards net job growth. This is not to refute that some type of firms may be more productive than others in creating new jobs and contributing to economic growth, in the same way that some entrepreneurs are more successful than others. In fact, the critique is in concordance

\footnotetext{
${ }^{1}$ See, for instance, Bartelsman et al. (2004, 2005), Birch (2006), Brown et al. (2006), Caballero (2007), and Fogel et al. (2008) for empirical evidence that churning and growth are strong correlates. A suggested explanation is that churning accelerates the discovery procedure of new business opportunities and a rapid reallocation of resources from unsuccessful to successful firms (e.g. Johansson, 2005).
} 
with Schumpeter's (1942) description of capitalism as a process of creative destruction where novel ideas continuously challenge old structures, thereby giving rise to structural transformation when new successful innovations, products, firms and industries arise while obsolete ones decline and vanish. It is also in line with evidence from recent research showing that the employment effect of new firm entry tends to follow a "wave pattern". Initially employment increases due to hiring by entering firms, composing the direct effect. Thereafter employment declines as a result of exits by both failed newcomers and crowding out of incumbent firms that have lower productivity levels than the successful newcomers. Finally, positive supply-side effects increase employment in the long run (Fritsch and Mueller, 2004; Fritsch and Noseleit, 2009). Accordingly, the conditions for structural transformation are decisive for economic growth. Empirical studies point out $\mathrm{HGFs}^{2}$ —or high-impact firms as Acs et al. (2008) and Acs (2010)) puts it - to be the main drivers of this process, which motivates indepth analyses of HGFs.

Despite the heterogeneity across the studies in several dimensions, Henrekson and Johansson (2010) conclude that some general findings emerge:

- All studies report HGFs to be crucial for net job growth compared to nonHGFs. They generate a large share of all, or more than all (in the case where employment shrinks in non-HGFs), new net jobs. This is particularly pronounced in recessions when HGFs continue to grow, while non-HGFs decline or exit.

- $\quad$ Several studies, particularly the ones concerning the U.S., find that HGFs provide a large share of new net jobs relative to total job growth in the economy and total unemployment.

- $\quad$ Small firms are overrepresented among HGFs, but HGFs are of all sizes. In particular, larger firms are important job contributors in absolute terms. A small sub-group of large HGFs - sometimes called Superstars or super Gazelles-are major job creators.

\footnotetext{
${ }^{2}$ For early evidence see Birch and Medoff (1994) and Storey (1994). More recent studies include Schreyer (2000) and Acs and Mueller (2008).
} 
- $\quad$ Age is of great importance. All studies reporting firm age conclude HGFs to be younger on average. Super Gazelles are also relatively young. HGFs are overrepresented in young and growing industries with a large inflow of new firms.

- $\quad$ Young and small HGFs grow organically to a larger extent than large and old HGFs, and therefore make a larger contribution to net employment growth.

- HGFs are present in all industries. There is no evidence that they are overrepresented in high-tech industries. If anything, HGFs appear to be overrepresented in service industries.

On the basis of this meta-analysis, we conclude that HGFs are instrumental to economic growth and net job creation, in particular those HGFs that start growing rapidly when young and small.

The purpose of this essay is to discuss institutions and policies conducive to the expansion of HGFs and therefore to structural transformation. We use North's (1990, p. 3) definition of institutions: 'the rules of the game in society, or more formally, the humanly devised constraints that shape human interaction.'

Institutions can be both formal- "hard"-(laws and regulations) and informal"soft"-(habits, norms, conventions etc.). Here we almost exclusively deal with formal institutions. This is not to deny that informal institutions such as networks, culture, codes of conduct, and trust are also very important. Although limiting the analysis to formal institutions is admittedly a simplification, it is of less concern than one would expect for a number of reasons, for instance, because informal institutions are harder both to enact and to analyze and since informal rules are not imposed through explicit political/collective decisions they cannot be directly influenced by policy. ${ }^{3}$

Obviously, the institutions we analyze in this chapter also affect the non-HGFs. However, we still believe that it is warranted to focus on the HGFs. The reason is

\footnotetext{
${ }^{3}$ Furthermore, a formal institution that is not enforced is likely to lose its practical relevance, and effective formal institutions become codified in society in the form of norms, habits and other informal institutions. In short, informal institutions are endogenous, i.e. the consequence of a certain set of policies and formal institutions - see, e.g. Lindbeck et al. (1999) and Kasper and Streit (1998) — and effective formal institutions are consistent with existing informal institutions (Williamson 2009).
} 
straightforward: If certain institutions affect HGFs relatively strongly and if HGFs are of crucial importance, then the effect of institutions on HGFs is of particular relevance for growth. At first sight, this seems to contradict the story concerning the direct and indirect effects of new businesses formation on growth, since the development of HGFs represents only the direct effect. However, strong start-ups represent a rather serious challenge for the incumbents and thereby induce indirect effects (Fritsch and Noseleit, 2009).

We use Schumpeter's (1934) theory of economic development as a starting point for the analysis (Section 2). Long-run growth results from the introduction and diffusion of profitable new combinations - novel ideas-into the economic system. Schumpeter emphasized this to be a human-driven process and recognized inventors, entrepreneurs, creditors and imitators to be key actors - each one performing a crucial economic function. We identify the constellation of actors with different but complementary competencies necessary to generate large-scale economic development and structural transformation.

Thereafter, we integrate institutional theory into the analysis. Institutions, and in particular private property rights, shape the incentives of economic actors and the functioning of markets. Modern societies are rich webs of formal and informal institutions that differ greatly. A complete analysis of the effects of institutions on HGFs and structural transformation is therefore an immense task, which is beyond the scope of this essay. In three subsequent sections, we address three institutional systems identified as hampering HGFs and structural transformation. In what follows we will in turn deal with the effect on potential HGFs and structural transformation of institutions affecting freedom of enterprising - as in the right and opportunity for the different types of actors to establish enterprises producing goods and services with the objective to make a profit (Section 3), institutions governing the labor market (Section 4), and the tax system (Section 5). The essay ends with some concluding remarks (Section 6).

\section{The crucial agents and their competencies}

Wealth, measured as Gross Domestic Product (GDP) per capita, has developed slowly — if at all — for all but the most recent part of the history of mankind. The 
industrial revolution broke this trend in development and since then wealth has surged (Figure 1).

\section{[Figure 1]}

In this essay, we deal with two main explanations that have been put forward to explain this historical shift:

- $\quad$ First, the accumulation and use of new productive knowledge including a far driven division and specialization of labor (Smith 1776);

- $\quad$ Second, the establishment and protection of private property rights (North and Thomas, 1973; Rosenberg and Birdzell, 1986; Mokyr, 1990; Jones, 2001; Acemoglu et al., 2005).

Relating to the first point, Schumpeter (1934) asserts that producing the same goods in the same way results in a stagnant economy. Change is therefore a central concept for Schumpeter's theory and the purpose of his seminal book is to present a theory of economic development explaining change - and economic growth - as an endogenous process. ${ }^{4}$ Change emanates from the generation, introduction and dissemination of novel ideas on how to combine resources more efficiently. ${ }^{5}$ Schumpeter distinguishes between novel ideas - inventions - and the introduction of these ideas into the economy-innovations. Economic development is defined as putting new combinations into use. ${ }^{6}$ It is an endogenous process since it is driven by actors within the economic system. Schumpeter identifies four actors as critical according to the economic function they carry out: inventors who come up with novel ideas, entrepreneurs who introduce new combinations into the economic system, creditors who finance the enterprises of the entrepreneurs, and imitators who disseminate innovations through copying and commercializing them in competing firms. Hence, in order to achieve large-scale

\footnotetext{
${ }^{4}$ Schumpeter (1934, p. 63): 'It is just this occurrence of the "revolutionary" change that is our problem, the problem of economic development in a very narrow and formal sense. ... By "development", therefore, we shall understand only such changes in economic life as are not forced upon it from without but arise by its own initiative from within.'

${ }^{5}$ Relating to Hayek $(1937,1945,1978)$, this can be seen as the generation and use of new productive knowledge.

${ }^{6}$ Schumpeter (1934, p. 68): 'The carrying out of new combinations means, therefore, simply the different employment of the economic system's existing supplies of productive means - which might provide a second definition of development in our sense.'
} 
industrial growth a set of actors with different but complementary competencies is required to generate, identify, select and exploit new combinations. ${ }^{7}$

We extend Schumpeter's list and identify six key categories of actors:

1) Inventors fulfill the same function as in Schumpeter's theory. They have detailed knowledge about products and solve specific problems of technical as well as of organizational and economic nature.

2) Entrepreneurs identify novel ideas about new combinations and introduce those with expected profitability into the market. They may be characterized as agents of change and fulfill a fundamental coordinating and judgmental function. ${ }^{8}$ Compared to Schumpeter, the entrepreneur plays a more restricted role. Part of his/her function is carried out by the industrialists.

3) Industrialists are active after the entrepreneurial phase and organize the further commercialization of the innovation into large-scale businesses. They carry out the function of the Schumpeterian entrepreneur in later phases and the function of the Schumpeterian imitator. The reason for unraveling the entrepreneurial function is that there is empirical evidence that the introduction of new ideas into the economy and the subsequent development of the original innovations into large-scale businesses generally require two separate competencies (Flamholtz, 1986; Baumol, 2004). Like in Schumpeter's theory, one individual can carry out more than one function and the original entrepreneur may evolve into an industrialist.

4) Financiers supply capital in the form of equity or loans. We recognize the empirical evidence establishing the importance of distinct categories of investors specializing in investing in different phases of the lifecycle of HGFs. We therefore prefer the term "financiers" before the term "creditors" to encompass these actors. In addition to capital, financiers provide management skills, industry-specific knowledge and access to business networks necessary for rapid firm growth. Venture capitalists supply

\footnotetext{
${ }^{7}$ See Johansson (2010) and Eliasson and Eliasson (1996) for a further discussion. The idea of the importance of complementary competencies to generate growth is recognized by a number of research scholars. See, for instance, Phelps (2007, p. 553) for a discussion in conformity with our analysis. ${ }^{8}$ A profitable venture for the individual entrepreneur may, however, have a zero (unproductive entrepreneurship) or negative (destructive entrepreneurship) social rate of return. Productive
} 
enterprises in early phases of business ventures with capital and actors in the secondary markets carry out similar functions, but at a later stage when entrepreneurs and venture capitalists want to exit from their investments. There are several types of actors in secondary markets, notably portfolio investors in publicly listed companies, private equity (PE) firms, and management buy-ins. Research also identifies business angels as providing a similar role as venture capitalist, but in an earlier phase. ${ }^{9}$

5) Skilled labor. Economic development and economic growth requires labor with relevant professional skills. The lack of individuals with specific skills may become a bottleneck for further expansion of HGFs and dampen structural transformation.

6) Competent customers provide the entrepreneur with information about their preferences. The ability to discern the preferences of the customers, so that highly-valued goods and services are produced, is a key ingredient in successful entrepreneurship; see von Hippel (2007) and Bhidé (2008) for recent examples. Competent customers should be representative of large groups of customers and can be both firms and individuals. Large enterprises can also function as competent financiers and finance the development of particular products, as exemplified by the biotechnology industry (e.g. Lerner and Merges, 1998; Audretsch and Feldman, 2003).

The actors start firms to exploit business ideas, and innovations are commercialized in both new and established firms. If the actors are successful their firms expand, but if they fail to generate sustainable profits their firms exit. Figure 2 schematically summarizes the role of the various actors in the process of fostering HGFs. The figure provides a stylized representation of the categories of actors needed in the various growth phases of HGFs (the development of a business idea, introduction, early growth, and rapid growth into a large-scale firm). Some categories may be important in several phases and a certain individual can fulfill several functions either simultaneously or at different points in the individual's or firm's life cycle. In a stylized form, the

entrepreneurs perform entrepreneurial activities where the social outcome is positive and based on wealth generation (Baumol, 1990).

${ }_{9}^{9}$ See Wright (2007) for an overview of the different categories and Prowse (1998) for an analysis of the function of the private equity market. Gompers and Lerner (2001) offer a comprehensive analysis of the importance of venture capital for innovation and firm growth. See also Landström (2007). 
development of rapidly growing firms may be depicted as an S-shaped curve. Most HGFs do not display sustained growth, but follow a more complex pattern (Parker et al., 2010). The figure shows at which stage of a firm's growth different categories play a key role. The order in which the categories appear beneath the boxes indicates which actor that has the main coordinating responsibility.

This is not a definite ranking and in practice it differs across enterprises, but a stylized depiction of what we believe is the typical situation. In the first phase, entrepreneurs together with competent customers identify potential business opportunities. Inventors are engaged to solve specific problems. The first phase of commercialization (introduction and early growth of firms) involves entrepreneurs, while skilled workers are involved to a small extent only. Industrialists are active in the phase of industrialization and rapid growth, which also requires a great deal of skilled labor. Venture capitalists are important financiers in the earlier phases. In later phases when the firm is larger, this role is taken over by actors in secondary markets. Competent customers are typically involved in all phases and ultimately (together with other customers) determine the demand for the good.

\section{[Figure 2]}

The economic activities of the actors give rise to a dynamic process of creative destruction - channeled via firm entry, expansion, contraction and exit—which brings about structural transformation in the perennial struggle between new and old structures. In what follows we focus on the effects of institutions on the establishment, growth and exit of HGFs. We aim to answer the question how should institutions be designed to promote HGFs?

Our approach relates to the literature on "technological regimes" pioneered by Winter (1984). In particular, a distinction has been made between 'entrepreneurial' and 'routinized' regimes (Audretsch, 1995). An entrepreneurial regime is found to apply in early stages of a product or industry life cycle, where knowledge is new and dispersed, development is driven by product innovation, firm entry and entrepreneurship, while scale economies are of minor importance. By contrast, a routinized regime applies to later stages of an industry or a product life cycle, when products and knowledge have become more standardized. In this regime scale economies and process innovation hold 
center stage, and large incumbent firms tend to predominate. The entrepreneurial regime relates to the early phases of the process of creative destruction when novel ideas are introduced and new technologies are discovered. The routinized regime relates to the later phases when the technologies are exploited. In the later phase the industry has probably undergone a period of shake-out and is dominated by a small number of firms (cf. Klepper and Simons, 2005).

Audretsch and Fritsch (2002), Fritsch (2004) and Fritsch and Mueller (2006) have extended the use of the regimes concept to geographical units, notably regions. The idea being that the mode of production in a certain region may be distinct from the dominant modes of production in other regions. This suggests that regional growth may be spurred by different kinds of economic policies depending on the knowledge conditions underlying the industries represented in different regions.

Linking to our analysis, regional regime is not a choice variable; it can rather be seen as the outcome of a historical process of structural transformation and is therefore strongly path dependent. This is all the more clear since the formal institutional setup is for the most part national rather than regional, and yet there could exist large regional differences in technological regimes. ${ }^{10}$ Hence, the concept of regional growth regimes provides a good ex post characterization of how the production system has evolved in a particular region. We believe that our approach complements the concept of growth regimes and provides a useful a tool for policy guidance, since it focuses on the interaction and complementarity of different categories of key actors necessary to build a HGF and their incentives.

\section{Freedom of enterprising and/or the regulation of product markets}

Since HGFs are prime movers of structural transformation, we begin by discussing the effect of free enterprising restrictions on the prevalence of HGFs. With free enterprising we mean the right to establish profit seeking firms producing goods and services. This gives consumers the option to buy preferred quantities and qualities at offered prices from different suppliers. In recent decades, developed countries have experienced a wave of deregulations aimed at increasing the contestability of markets and providing

\footnotetext{
${ }^{10}$ Two famous examples are the difference between Route 128 in Boston and Silicon Valley (Saxenian, 1996) and the distinct difference between East and West Germany (Fritsch, 2004).
} 
more opportunities for private entrepreneurship, e.g. in telecommunications, transportation and financial services. This can be expected to lead to greater scope for the emergence of HGFs.

However, one central segment of many advanced economies remains heavily regulated and in some cases even monopolized by the public sector: The provision of private-good social services such as health care, care of children and the elderly, and education. The social benefits from further deregulations fostering HGFs in these areas are likely to be substantial (although the difficulties arising from asymmetric information and moral hazard are no doubt often greater here than in other areas). These industries already constitute a considerable share of GDP: About 20 percent of GDP in the OECD, and even more (about 30 percent) in the Scandinavian welfare states (Adema, 2001; Adema and Ladaique, 2005; Andersen, 2008). These industries will meet an increasing demand from aging and wealthier populations. The income elasticity of services provided by these industries has been estimated to be as high as 1.6 (Fogel, 1999). While several of these markets have been partially opened for private competition in recent years, many impediments are still in place, with private firms still producing only a fraction of total output. We discuss three combinations of restrictions separately: (i) the case where both production and financing are monopolized by government, i.e. government controls production and prices and pays for the services; (ii) the case where production is monopolized by government, but private financing is allowed; and (iii) the case where private production is allowed but financing comes from the government.

\subsection{Public production and public financing}

Private entrepreneurs cannot play any role if the provision of goods and services is monopolized by government. Business angels, venture capitalists and actors in the secondary market will not be present, since there are no investment opportunities. The build-up of industrial competence is negligible when the acquisition and use of such competence is restricted. While research and development may be subsidized, the incentives for inventors themselves are weakened since there will be no competitive markets for potentially successful inventions. The labor market is monopsonized, i.e. there is only one employer, which tends to lower wages for skilled workers, inducing a 
scarcity of skilled workers. ${ }^{11}$ Competent customers will be scant and unable to affect production.

This will hamper structural transformation, since the essence of entrepreneurial, industrial, business angels, venture capital and secondary market actor functions is to generate profit through the use of new productive knowledge commercialized in competitive markets. These competencies are acquired through individual learning-bydoing in profit-driven firms and can rarely be substituted by competence obtained in political organizations (Pelikan, 1993). ${ }^{12}$ As a result, HGFs will not form, dampening structural transformation. Today, there are very few markets in democratic societies where government monopolizes both production and financing with one notable exception: higher education.

\subsection{Public production and private financing}

There are a few markets, mainly infrastructure, where government monopolizes production, but where private financing is allowed, even as the main source of funding. Electricity supply, garbage collection, telecommunications, postal services, public transportation and water supply are still prime examples in many countries. Here too, we observe an ongoing deregulation. To exemplify: Personal transports on railway were until recently monopolized in most European countries. Now a partial deregulation has taken place opening up the market for private and international providers in many EU countries.

Revoking the restriction on private financing while keeping production under government control does not change the effect on HGFs and structural transformation compared to the case of government monopolization of both product and financing markets. In this setting critical entrepreneurial competence can hardly exist. Public enterprises sometimes have intrapreneurs, e.g. hospital managers, school principals or college deans that improve performance through innovation and the build-up of structural capital. But in this system establishments that are better managed or otherwise

\footnotetext{
${ }^{11}$ See, e.g. Hibbs and Locking (2000)

${ }^{12}$ In this context, private firms can be seen as "universities" for educating talented people (cf. Eliasson and Vikersjö, 1999). In line with this way of reasoning, small firms may function as a cost-efficient mechanism to identify, select and develop entrepreneurial, industrial and venture capital competencies. Failures are less costly and learning costs lower in small firms because small values are at stake (Lucas, 1978).
} 
above average in performance have weak incentives and far less opportunities to expand and improve quality across the board. Business angel and venture capitalist competencies still cannot exist, and industrialist competencies are hard to acquire, attract and utilize. State ownership makes management less interested in innovation activities, since it is more difficult for them to reap any benefits from these activities compared to private owners (e.g. Shleifer, 1998). ${ }^{13}$ This implies that it is difficult for inventors to earn returns on their efforts in excess of their salary, which in general is much less than the market value of potentially successful inventions. ${ }^{14}$ The monopsonized labor market will also make the salaries lower than in a market with many competing producers, leading to poor incentives to acquire high skills.

\subsection{Private production and public financing}

Welfare states increasingly recognize that ensuring access to health care and other social goods and services does not require government production of such goods, only public financing. Hence, market-type mechanisms ${ }^{15}$ that combine private provision and public financing of these services are increasingly utilized. Outsourcing, vouchers and publicprivate partnerships are the three most common arrangements. Deregulating markets previously closed to private entrepreneurship through these strategies increases the economy's potential to generate HGFs. But the remaining regulation may still cause problems for future HGFs. First, the government is a monopsonist. Consumers are entitled to specific goods or services at reduced costs or free of charge, but only from providers commissioned by government. ${ }^{16}$ The providers typically have limited options

\footnotetext{
${ }^{13}$ Hart et al. (1997, p. 1131) argue that the focus on quality changes from innovative activities differ from traditional approaches in the literature on regulation and procurement, e.g. Laffont and Tirole (1993), who study issues like adverse selection and moral hazard stemming from incomplete information in contracting.

${ }^{14}$ This should be separated from the rate of innovation for inputs purchased by the government from private firms, such as pharmaceuticals and medical equipment. Winston (1998) provides empirical examples of how the transfer of ownership from the government to private actors positively affects the creation and adoption of new technologies.

${ }^{15}$ OECD (2005, p. 130) defines a market-type mechanism as 'encompassing all arrangements where at least one significant characteristic of markets is present.'

${ }^{16}$ One reason could be that the government wants to ascertain that service providers offer a minimum level of quality, for instance, concerning health care. Shleifer (1998) suggests that in the case where monitoring costs are high and private firms have incentives to shirk on quality, a government-managed organization may even have some advantages over private alternatives. These alternative mechanisms can mitigate the problems associated with the removal of market forces, but are unlikely to fully offset the costs, especially since the market can be combined with alternative ways of influencing producers (Le Grand, 2007).
} 
to offer and charge for additional quality on top of what is granted through the taxfinanced system. These restrictions bar customers from buying their preferred qualities or services in preferred quantities from preferred providers. The growth of potential HGFs may then slow down - or even stop altogether - due to restrictions on attracting customers. As a result, reallocation and structural transformation will be dampened.

Second, it is common that government crowds out private producers in markets like health care and non-mandatory schooling. A common strategy is to offer services free of charge, financed through taxes in combination with the banning of customers from being eligible for any subsidies when buying from private suppliers. Such policies may imply a de facto ban on private entrepreneurship in these markets, even though not explicitly prohibited by law. This does not suggest that health care and other welfare services should not be publicly financed, rather it implies that the fostering of HGFs and structural transformation are encouraged by a policy where private producers are entitled to the subsidies if the patients or customers prefer a private producer to a public producer, i.e. the subsidy should follow the patient/customer, like in a voucher system. In many instances opening previously monopolized markets to private providers has led to impressive performance of HGFs suggesting that there is a large untapped potential for this in sectors such as health care, education and care of children and the elderly. One such example is the voucher system for school choice that was introduced in Sweden in the early 1990s, which paved the way for several HGFs in the area. At about the same time local and regional governments began to outsource health care, and from this a number of HGFs have emerged. Some of them have since become multinationals. $^{17}$

Sometimes it is suggested that private firms providing publicly financed services should be prohibited from making profit and required to reinvest all surplus in the firm. ${ }^{18}$ Such provision constitutes no impediment for private non-profit foundations (such as universities and many U.S. hospitals). However, a de facto ban on profit will have the same effect on HGFs and structural transformation as the government monopolizing production. Even though there will exist a strong demand for, for

\footnotetext{
${ }^{17}$ One of the most well-known examples is the health care provider Capio, which was founded in Sweden in 1994. In 2008 Capio had 16,500 employees in eight countries. There are also several large operators in elderly care, which are gradually becoming multinational as well.

${ }^{18}$ This was explicitly suggested by a government expert investigation in Sweden in 2002 (SOU 2002:31).
} 
example, private schools, this will weaken profit incentives for entrepreneurs and reduce business opportunities for venture capitalists. Consequently, there will be no HGFs and structural transformation will be slow.

A major disadvantage of prohibiting private financing is the lack of signaling from spending decisions by competent customers, since all private customers are excluded. The mixture of private production and public financing is therefore expected to prevent the formation of complete sets of actors with the requisite complementary competencies; and lacking private customers, few HGFs are expected. ${ }^{19}$ Table 1 provides a summary of the analysis. The benchmark case is private production and private financing, when there are no legal restrictions barring the formation of sets of actors possessing all required competencies, rapidly growing firms and fast structural transformation. The analysis reveals that thriving HGFs require free private provision of goods and services and private financing. Only then can the incentives be (reasonably) harmonized for all required key actors, thereby providing favorable circumstances for HGFs.

\section{[Table 1]}

\section{The organization of labor markets, the prevalence of HGFs and structural transformation}

Rapid firm growth and structural transformation presupposes the reallocation of labor from low-productivity to high-productivity firms and industries. Labor studies document massive ongoing restructuring of jobs and workers across firms (Abowd and Kramarz, 1999; Davis and Haltiwanger, 1999; Caballero, 2007). It is reasonable to hypothesize that current and future HGFs are more in need of flexibility and freedom of contracting in order to reach their potential high-growth. Institutions hampering the freedom of contracting curtail the possible combinations of factors of production. The large productivity differentials across firms in the same industry indicate that labor productivity controlling for skills/competencies can vary dramatically depending on who is the manager/entrepreneur (Lucas, 1978; Pelikan, 1993; Caballero, 2007).

\footnotetext{
${ }^{19}$ An exception is when the government purchases goods and services for their core activities, such as national defense.
} 
In this section we will examine the impact of labor market institutions on the functioning and efficiency of key competencies. We focus on three labor market institutions of particular importance for the economy's ability to generate HGFs and to promote structural transformation: (i) Wage-setting institutions; (ii) employment protection legislation; and (iii) the social insurance system.

\subsection{Wage-setting institutions}

Wage-setting institutions may impact the scope for cooperation between key actors with complementary competencies, and the conditions for (potential) HGFs and structural transformation through several channels. In particular, the wage compression associated with centralized wage bargaining is likely to disadvantage potential HGFs, since an artificially compressed wage structure in both tails of the distribution makes it more difficult for profitable firms with high productivity to use salaries as an incentive to recruit new productive employees, making expansion more difficult to realize. This effect is reinforced if taxes are progressive. Minimum wages set above the market equilibrium level, on the other hand, forces low-profit firms with low productivity out of business. Start-ups generally tend to be low-wage firms in the beginning due to their relatively low productivity before they reach the minimum efficient scale of the industry (Audretsch, 2002). A study by Halabisky et al. (2006), demonstrates HGFs to be lowsalary companies in the beginning of their life cycle and large firms in slowly growing industries to be high-salary companies. When young potential HGFs realize their growth potential and begin to grow rapidly, salaries start to grow fast. They conclude (Halabisky et al., 2006, p. 265): 'In other words, for small firms, wage levels were highest in those that grew the fastest.' The finding suggests that a compressed wage structure pegging minimum wages above the market equilibrium level tends to choke potential HGFs in their infancy. They cannot bear high wage costs in the beginning of their life cycle when still developing their product and in the early phase of commercialization before the firm has become more productive and could afford to pay higher salaries.

Empirical studies find HGFs to be younger and smaller than other firms on average and most likely to be in the services sector. Wages are consistently higher at larger firms, even after exhaustive efforts to control for observable worker characteristics and 
other job attributes (Oi and Idson, 1999). Old firms pay higher wages than new firms on average and industries in the low-end of the wage distribution are found in services, not in manufacturing. ${ }^{20}$ Hence, the negative effect of wage compression is reinforced by the fact that wage compression disadvantages firms that are most likely infant HGFs.

Also, centralized wage-setting institutions disadvantage potential HGFs by implementing standard rate compensation policies that closely tie wages to easily observable job and worker characteristics such as occupation, education, experience and seniority. ${ }^{21}$ In their study of the size-wage structure in the U.S. manufacturing sector, Davis and Haltiwanger (1996) find that residual wage dispersion declines sharply with establishment size in standard human capital regressions that relate worker earnings to sex, education, experience, and job tenure.

Given the large intra-firm differences in productivity and productivity growth, in particular in young and rapidly expanding industries and young firms (Caballero, 2007), it follows that the functioning of the cooperation of different key actors needed for HGFs is impaired if wages are set in negotiations far from the individual workplace, and therefore not taking these facts into proper account.

\subsection{Employment protection legislation}

There are large cross-country differences concerning employment protection legislation (EPL) (Skedinger, 2010). There is a risk that rigid labor market legislation locks in employees in current firms and industries, which is at odds with the needs of rapidly growing firms. For instance, strict application of the principle of 'last in-first out' in case of redundancies implies that tenure at the current employer becomes relatively more important for labor security than individual skill and productivity. This fact increases an employee's opportunity cost of changing employers or of leaving a secure salaried job. There may be room for making exceptions from the 'last in - first out' rule. Often this requires union consent, and exceptions are therefore granted through negotiations between the employer and the union, not by the employer. Irrespective of

\footnotetext{
${ }^{20}$ Garen (1985) and Kremer (1993) develop theoretical models that explain the systematic sorting of more productive workers to larger employers as an efficiency-enhancing outcome in economies with heterogeneous, imperfectly substitutable labor.

${ }^{21}$ Freeman (1988), Blanchflower and Freeman (1992) and Blau and Kahn (1996) provide evidence that unions and other centralized wage-setting institutions compress wages among observationally similar workers by promoting standard rate compensation policies.
} 
skill, an employee can never be sure of the outcome of such negotiations. Hence, there will always be an opportunity cost, also for high-skill workers, to give up a long-tenured position for a new job. This will make it more difficult for rapidly expanding firms to hire skilled workers. The risk of growth dampening bottle-necks in production increases.

The empirical findings about churning and restructuring give reasons to believe that in particular strict employment security provisions and other regulations that restrict contracting flexibility are more harmful for enterprises that would like to grow rapidly. As an employer learns about a worker's abilities over time, or as those abilities evolve with experience on the job, the optimal assignment of the worker to various tasks is likely to change. The scope for task reassignment within the firm can be expected to rise with firm size. In an unfettered labor market, optimal task reassignment often involves mobility between firms, and such mobility is higher when the initial employment relationship involves a small, often young, business. For instance, Schnabel et al. (2008) report that employment stability (measured as time employed in the same firm) is higher and the risk for becoming unemployed lower in incumbent firms than in newly founded firms. Moreover, both the rate at which workers separate from jobs and the rate at which employers destroy job positions decline with the size, age and capital intensity of the employer (Brown and Medoff, 1989; Davis and Haltiwanger, 1999). Bartelsman et al. (2004, p. 4) claim that there is much more churning among young and small firms compared to old and large ones. In a meta-analysis of employment creation studies, van Praag and Versloot (2007, p. 360) conclude that 'employment dynamics are larger in entrepreneurial firms'. ${ }^{22}$ These patterns in worker separation and job destruction rates suggest that any costs imposed by EPL are likely to fall more heavily on younger, smaller and less capital-intensive (often service) employers. Since HGFs are overrepresented in these categories, this implies that a stringent EPL disproportionately burden HGFs. Another important argument is provided by the "varieties of capitalism" literature (Hall and Soskice, 2001), where it is argued that employment protection legislation harms particularly innovative firms and start-ups because these firms are faced with an exceptional degree of uncertainty and have a special need for flexibility.

\footnotetext{
${ }^{22}$ They define entrepreneurial firms as smaller and younger firms.
} 
If regular employment is highly regulated there may be strong incentives to devise arrangements that circumvent these regulations. In several European countries new forms of flexibility have emerged, leading to more job opportunities (Blau and Kahn, 1999; Skedinger, 2010). The most important of these arrangements are increased selfemployment, the emergence of an underground economy where the government refrains from enforcing regulations, and increased reliance on temporary employment. ${ }^{23}$ It is likely that part of the increase in self-employment in recent years is driven by such considerations. For the self-employed, compensation and working hours are totally unregulated and no labor security is mandated. Also, very small firms may be able to avoid unionization and the signing of collective agreements, and therefore benefit from greater freedom of contracting. This room of maneuver is likely to be lost once the firm size exceeds a certain threshold. Therefore, these evasive measures do little to help HGFs and welfare-enhancing structural transformation. Instead, they tend to create a system with a large share of economic activity occurring in small firms without the ability or the aspiration to become HGFs. ${ }^{24}$

The differential effect of labor market regulations may go a long way towards explaining why the rate of self-employment is fairly low in the U.S., while it is very high in Italy. One may hypothesize that in the U.S. the really good entrepreneurial firms are more likely to grow rapidly, while the onerous regulation, possibly in combination with the high tax rates on labor income, makes it difficult and risky to build large firms in Italy. Instead, the firms tend to remain small and resort to a strategy of cooperation with other small firms in clusters (Lazerson and Lorenzoni, 1999).

\subsection{The social insurance system}

The design of the social insurance system also affects the conditions for HGFs and structural transformation. One argument in favor of a relatively generous insurance system is that it enhances structural transformation. It is plausible that a rapid structural transformation is correlated with a high turnover of jobs making people temporarily unemployed. A well functioning insurance system will then provide income security

\footnotetext{
${ }^{23}$ Arai and Heyman (2004) report that temporary job flows in Sweden in the 1990s were as much as ten times higher than job flows for permanent contracts. See also Shane (2008).

${ }^{24}$ These opposing effects are also consistent with the findings of Robson (2003) and Torrini (2005), who do not find any relationship between the rate of self-employment and the degree of regulation of labor markets in rich countries.
} 
during periods of unemployment making people more supportive of fast transformation. A counterargument is that too generous a social insurance system may in practice work as a source of income substituting for paid employment. In this case, the social insurance system increases the reservation wage which is likely to hamper structural transformation.

The design of the social insurance system may also affect individuals' incentives to establish and expand firms. Sinn (1996) argues that by providing insurance for unfavorable outcomes, an extensive and generous public social insurance system can in principle encourage individuals to pursue entrepreneurial endeavors. This is a valid theoretical argument but it is an open question whether it is important empirically. At first sight it appears more clear-cut that a generous welfare system makes it less costly to bear uncertainty as an entrepreneur or transfer to a risky job in an entrepreneurial firm. In labor markets where job security is closely linked to job tenure, this may no longer hold; what matters is the opportunity cost, i.e. how much an employee has to give up in terms of income security if (s)he transfers to self-employment or a risky job in an entrepreneurial firm.

We can illustrate this point by comparing the situation in Sweden and Denmark. In Denmark, generous welfare systems are combined with weak job security mandates, sometimes called "flexicurity" (Andersen, 2005). In Sweden, the situation is very different. If employment with the current employer has lasted for a long time, and the employer is unlikely to be forced to shut down, the system in reality provides income security for the individual. ${ }^{25}$ By contrast, somebody who voluntarily gives up a tenured position for self-employment may often end up having no more security than what is provided by social welfare, and this presupposes that the individual depletes all her own assets. Hence, the construction of the public income insurance systems in combination with the EPL tends to penalize individuals who assume entrepreneurial risk. As a result, the opportunity cost of giving up a tenured position in Denmark is substantially lower than in Sweden.

A final point concerns the design of the supplementary pension system and other important benefits that may be tied to employment, notably health insurance. Supplementary pension plans that are not fully actuarial and individualized contain 
elements of redistribution and risk-sharing across individuals in a group, e.g. the whitecollar workers in a certain industry. The pension benefit level may be disproportionately tied to the wage level achieved at the end of the professional career. To the extent that this is true, the mobility of (older) workers across firms is greatly discouraged, as well as the hiring of elderly unemployed.

\section{The tax code, the prevalence of HGFs and structural transformation}

The tax system is particularly important for the issue discussed here. Taxes invariably influence transactions in that they create a wedge between the net receipt of sellers and gross costs of buyers of a service or a product. Hence, taxes greatly influence the incentives to acquire and apply productive knowledge as well as the possibility to reallocate factors of production to more productive areas. Taxes can create lock-in effects of labor and capital. In Section 2 we identified six distinct categories of actors crucial for HGFs. However, the tax code only imperfectly acknowledges these categories; there is no specific tax on income from entrepreneurial effort or inventive activity. Instead, based on provisions in the tax code, individual income will be classified as labor income, capital income and/or corporate income, and within each of these categories there may be further provisions influencing the effective tax rate. In what follows we will examine how the incentives for the different categories of key actors are affected by the tax system.

\subsection{Labor taxation and sales tax/VAT}

The level and progressivity of labor taxation (including mandatory social security contributions) affect employees directly, by determining the incentives for work effort, labor supply (on the extensive and intensive margin), occupational choice, career aspirations, and the propensity to upgrade and learn new skills. Most obviously, high and progressive labor taxes lower the rate of return on productive skills, and therefore they are likely to reduce the supply of skilled workers. ${ }^{26}$ They also slow down

\footnotetext{
${ }^{25}$ This was true until 2006, but beginning in 2007 the Swedish government has implemented numerous measures that reduce the generosity and eligibility of the social insurance system for the unemployed. ${ }^{26}$ The incentives to acquire human capital through formal schooling may be strong thanks to low or zero tuition fees, subsidized student loans and housing financed by taxes, while high marginal taxes abate the incentives to use and further develop that kind of capital.
} 
restructuring and the reallocation of people across firms, since it becomes more costly to obtain the net wage differential necessary to induce a person to quit their current employment position.

To the extent that inventors are taxed as wage-earners their incentives are also affected by the tax code for labor income. The same is true for industrialists (those who carry out the function of the Schumpeterian imitator and the Schumpeterian entrepreneur in later phases of commercialization of the original innovation), unless they have a large ownership share in the firm they manage, which is usually not the case for large firms.

The level and progressivity of labor income taxation also indirectly affect the industry structure from the demand side. High rates of personal taxation tend to make it more profitable to shift a large share of service production to the informal economy, in particular into the 'do-it-yourself' sector. ${ }^{27}$ Cross-country comparisons of industry-level employment also point to considerable scope for substitution of certain economic activities between the market and non-market sectors (Rogerson, 2006; Freeman and Schettkat, 2005).

As a result, the emergence of a large, efficient service sector competing successfully with unpaid work is less likely in countries with high rates of personal taxation. Consequently, important opportunities for commercial exploitation and entrepreneurial business development become less accessible. When services are provided by professionals, incentives emerge to invest in new knowledge, to develop more effective tools, to develop superior contractual arrangements, to create more flexible organizational structures and so forth. Put simply, higher rates of personal taxation discourage the market provision of goods and services that substitute closely for homeproduced services. ${ }^{28}$

The incidence of commodity taxation generally falls on final domestic consumers, while intermediate goods and exports are exempted. Hence, the effects of these taxes on the different actors are similar to the effects of labor taxation although there is no

\footnotetext{
${ }^{27}$ This basic insight constitutes an important point of departure in recent work in the theory of optimal taxation. The theoretical results of Kleven et al. (2000) and Piggott and Whalley (2001) strongly suggest that the optimal tax structure involves a relatively low tax rate on those market-produced services that could alternatively be produced in the household sector. See also Jansson (2006).

${ }^{28}$ See Dew-Becker and Gordon (2008), Rogerson (2006) and Davis and Henrekson (2005) for assessments of these effects across OECD-countries.
} 
progressivity. Generally, there is considerable differentiation in sales/VAT taxation across countries and commodity groups.

\subsection{Taxation of stock options}

One mechanism to encourage and reward individuals supplying key competencies to a firm is the use of stock options. In ideal circumstances this can provide incentives that closely mimic direct ownership. This is likely to be most important for employed inventors, entrepreneurs and industrialists in certain industries where options are an effective response to agency problems.

The efficiency of stock options is highly dependent on the tax code. If gains on stock options are taxed as wage income when the stock options are tied to employment in the firm some of the incentive effect is lost. This is particularly true if the gains are subject to (uncapped) social security contributions and if the marginal tax rate is high.

The situation is very different if an employee who accepts stock options can defer the tax liability to the time when the stocks received upon exercise of the options are eventually sold. The effectiveness is further reinforced if there are no tax consequences to the employee upon the granting or the exercise of the option and if the employee is taxed at a low capital gains rate when the stock acquired through the exercise of the option is sold. In the latter case the tax risk of the options is pushed back to the government. This accomplishes two things: It increases the potential profit from the stock options and it allows budget-constrained individuals to sell stocks whenever they choose to do so. It is noteworthy that the U.S. changed the tax code in the early 1980s along the latter lines, which paved the way for a wave of entrepreneurial ventures in Silicon Valley and elsewhere (Misher, 1984; Gompers and Lerner, 2001).

\subsection{Taxation of venture capital and private equity activity}

Venture capitalists often fill a crucial role in the development of a small entrepreneurial high-growth venture by converting high-risk opportunities to a more acceptable risk level through portfolio diversification, and adding key competencies that the firm may be lacking. This is achieved by means of developing arrangements that align the incentives of the three actors-investors, venture capitalists and entrepreneurial startups (Zider, 1998; Gompers and Lerner, 2001). The extent to which this is possible is 
also largely governed by the tax code for stock options, capital gains, and whether pension funds are allowed to invest in high-risk securities issued by small or new companies and venture capital funds.

The tax systems of many countries evolved before complicated ownership structures involving VC/PE financing even existed. ${ }^{29}$ Sophisticated mechanisms were needed to provide high-powered incentives for a number of actors in addition to the final equity holders. In fact, the modern VC industry in the U.S. could not evolve until the tax system was changed in key respects: Sharp reductions in the capital gains tax, new legislation in 1979 allowing pension funds to invest in high-risk securities issued by small or new companies and venture capital funds, and stock option legislation of 1981 that made it possible to defer the tax liability to the time when the stocks were sold rather than when the options were exercised (Fenn et al., 1995).

In the U.S. investments by venture capital firms are taxed at low rates. The returns that venture capitalists receive when the companies they help build are sold (so-called carried interest) are taxed at the 15 per cent capital gains rate. For the founders of the startup the capital gains tax rate may be half of that level (up to a high cap), since half of the gains is tax exempt if the stock has been held for at least five years.

In Sweden, by contrast, domestically domiciled VC and PE firms are at a disadvantage relative to other firms. Until 2003 dividends were taxed threefold: At a rate of 28 per cent in both the firm itself and the VC firm and, when applicable, at 30 per cent at the owners' level. Since 2003 there is no taxation at the level of the VC or PE firm. And, business angels that take active part in the management of the firms in which they invest are taxed at a higher rate. Likewise, the income of the general partners in VC firms and income from and stock options tied to employment are taxed as wage income. Thus, the high rates of taxation of entrepreneurs, general partners of $\mathrm{VC}$ firms and the owners of the VC firms or the business angels result in a substantial reduction in the after-tax return on activities typical of VC firms in the U.S. This may

\footnotetext{
${ }^{29} \mathrm{VC}$ and PE ownership involves several layers of ownership: Private ownership stake by founders and key personnel, ownership share by VC/PE firm, ownership stake by VC/PE partners (often indirect), investor stake in the VC/PE fund and final beneficiaries of institutions investing in VC/PE funds.
} 
be an important factor explaining the fact that few Swedish firms founded in recent decades have grown to a large size. ${ }^{30}$

\subsection{Corporate taxation}

Following extensive tax reforms, corporate tax rates throughout the OECD countries have come down from very high levels in the 1980s. Cross-country variations in the statutory corporate tax rates, however, remained large until recently. For instance, in the early 2000s it exceeded 50 percent in Germany (by 2009 the German corporate rate had been lowered to roughly 16 percent) while it was no higher than 24 percent in Ireland and 18 percent in Hungary (2003). In general, there was a discrepancy between statutory and effective corporate income tax rates stemming from mechanisms such as tax-reducing depreciation rules, inventory valuation rules, and other more ad hoc tax reductions that may be country or industry specific. ${ }^{31}$ Seen from the perspective of the individual firm, opportunities for lowering the effective tax rate induce behavioral responses by firms, and to the extent that these opportunities differ depending on firm and industry characteristics, effects on HGFs and on structural transformation can be expected.

\subsection{Taxation of current capital income}

Current capital income consists of interest income and dividends on equity holdings.

Tax systems may differ in important respects here: (i) Labor income and capital income can either be summed and taxed according to the same tax schedule, and if the income tax is progressive this may result in very high taxes on capital income, in particular if the tax rate applies to nominal as opposed to real returns; (ii) capital income can be taxed separately from labor income, either at a flat or progressive rate with or without inflation adjustment; (iii) dividends may be taxed at a lower rate reflecting the fact that dividends as opposed to interest payments is a tax-deductible business cost for the firm; (iv) the tax code may put restrictions on the payment of dividends to the owners of closely held firms in order to prevent active owners from converting labor income into

\footnotetext{
${ }^{30}$ In 2004, among the 100 largest firms in Sweden, including firms formed by government and firms established by foreigners, there were 34 firms originally founded by Swedish entrepreneurs. The median year of establishment of these firms was 1908 and no one was founded after 1970 (Axelsson, 2006).

${ }^{31} \mathrm{See}$, for example, King and Fullerton (1984) and the studies contained therein.
} 
capital income taxed at a lower rate. ${ }^{32}$ Moreover, tax systems may differ as to whether deduction of interest payments is allowed (in real or nominal terms).

Hence, the tax code pertaining to current capital income has large incentive effects, especially for entrepreneurs and the functioning of secondary markets. In particular, if taxation is nominal and tax rates are high, the real rate of taxation - i.e., the combined effect of nominal taxation and inflation on the real rate of return on an investment - can easily exceed 100 per cent even at moderate inflation rates. On the other hand, this may be largely offset by tax deductibility of interest payments, and if certain investments are tax favored opportunities for tax arbitrage arise. ${ }^{33}$

\subsection{Taxation of capital gains}

Most of the economic return from the successful building of an HGF comes in the form of a steeply increased market value of its stock rather than as dividends or large interest payments to the owners. As a result, the taxation of capital gains on stock holdings has large effects on the incentives to create wealth through the fostering of HGFs.

There are large differences across countries and over time. In some countries the tax rate is zero or very low on capital gains on long-term holdings of equity, thereby providing strong incentives for entrepreneurs to create value by investing money and effort in their own business, and to give other key actors (industrialists and business angels) ownership stakes in the firm if their competencies are required. In other countries the reverse may be true, that is, the tax system penalizes owners of stock in closely held firms relative to owners of stock in listed firms in order to prevent owners of profitable small businesses from saving on taxes relative to the case where they are regular employees. ${ }^{34}$

\footnotetext{
${ }^{32}$ In this respect it is noteworthy that in the U.S. dividends in the so-called S-corporations are only taxed at the level of the owner's personal income tax (Cullen and Gordon, 2006).

${ }^{33}$ Fukao and Hanazaki (1987) provide systematic evidence of such effects for OECD countries in the 1970s and 1980s.

${ }^{34}$ This is the case in Sweden, where the legislator is concerned that owners of closely held firms do not convert labor income to capital income by paying themselves dividends taxed at 30 percent rather than wages taxed at the marginal tax rate for labor income. The scope for dividend payments is therefore restricted to a relatively small percentage of the equity capital paid in by owners. Similar provisions raise the capital gains tax on small businesses (Agell et al., 1998). In recent years it has normally been 43 percent for small closely held firms instead of the regular 30 percent, since half of the capital gain has been taxed as wage income.
} 
Moreover, the capital gains tax may differ across different types of owners, where some types of owners, such as institutional investors and offshore trust funds, are taxed at lower rates than individuals. This is likely to spur an endogenous response in the ownership structure of the business sector towards the tax-favored owner categories. Generally, if individual stock holdings are disfavored relative to institutional holdings this affects the functioning of secondary markets, giving more effective control rights to fund managers and less to final owners. In case owner competence is a scarce resource and ownership matters for potential HGFs, such tax rules tend to inhibit the emergence and growth of HGFs (cf. Pelikan, 1993). Empirical results demonstrate that the success of HGFs often is due to individual owners "of flesh and blood" playing a decisive role in critical phases of the life cycles of HGFs. These individuals have often generated their wealth through their own entrepreneurial activities when younger, and then become business angels or venture capitalists. Institutional holdings are managed by employees with other backgrounds lacking the experience and competence of these individual owners, which probably can only be acquired through learning-by-doing as entrepreneurs and private investors. Arguably, this competence is among the most valuable competencies in a market economy. An individual possessing this competence will therefore not work as an employee in general, but in his/her private company to fully reap the return on the competence.

\subsection{Taxation of asset holdings}

There are several types of taxes levied on asset holdings where the tax is decoupled from the return. This is true for taxes on wealth, property and inheritance. In cases where these taxes are non-zero, the rules for how taxable wealth is assessed in the business sector are particularly important in our context. Successful entrepreneurs, venture capitalists and actors in secondary markets have been shown to be highly sensitive to these kinds of taxes. ${ }^{35}$ In some systems corporate wealth may be exempted, which would spur investment in entrepreneurial ventures by key actors. Alternatively, corporate wealth may be taxed heavily, while other assets such as pension savings or art objects are exempted. Hence, taxes on asset holdings influence both the absolute and 
relative return on asset accumulation. In most cases where such taxes are levied the calculations are complicated; certain assets may be exempted and the imputed value used as the basis for assessments may be far below the market value. Again, HGFs tend to depend on individual owners during certain critical phases in their life cycle, and taxes on asset holding that give incentives for individual owners to shun direct ownership of unlisted stock is expected to affect HGFs negatively.

\subsection{Taxation at the ownership level}

To get a better understanding of the effect of the tax system on the prevalence of HGFs and the speed of structural transformation the combined effect of different taxes on the incentives to establish firms with high-growth ambitions have to be taken into account, including differences caused because of different sources of finance. For our purposes it is important to highlight whether there are any differences between small individually owned firms (incorporated or unincorporated) and institutionally owned firms, which are either listed or unlisted.

Estimating, in real terms, the size of the marginal tax burden faced by private firms for investment in real capital is a painstaking task requiring that we consider the overall effects of several different taxes, such as corporate taxation with its specific rules for depreciation and valuation, as well as the taxation of interest income, dividends, capital gains, and wealth. In addition, we need to consider how these tax schedules differ across different types of investors. A correct estimate of the tax burden must take into consideration which type of real capital the firms invest in, how these investments are financed, who the firm's owners and creditors are, and in what industries the investments are made. Estimates have been made for a number of countries using the methodology developed by King and Fullerton (1984).

We will use the Swedish tax system to illustrate how tax schedules affect HGFs. Table 2 presents effective marginal tax rates for different combinations of owners and sources of finance for Sweden in 1980 and 1994. Three categories of owners and sources of finance are identified, and the effective marginal tax rate is calculated

\footnotetext{
${ }^{35}$ See Rosen (2005) for an overview. In Sweden the emigration of successful entrepreneurs was extensive due to very high effective taxes on wealth and inheritance, particularly during the 1970s and the 1980s (Lindqvist, 1990).
} 
assuming a real pre-tax rate of return of 10 percent. A negative number means that the real rate of return is greater after tax than before tax.

The table highlights several aspects of the tax system that are potentially important determinants of HGF activity. First, in 1980 debt financing received the most favorable tax treatment and new share issues the least favorable treatment. Second, the taxation of households as owners was much higher than for other categories. In fact, more than 100 percent of the real rate of return was taxed away for a household buying a newly issued share. Third, tax-exempt institutions benefited from a large tax advantage relative to the other two categories of owners. Tax-exempt institutions had a substantial relative tax advantage throughout when investing in newly issued shares. ${ }^{36}$ Fourth, insurance companies were in an intermediate position in terms of effective taxation. As shown by Davis and Henrekson (1997) the tax system favored large and old manufacturing firms. By implication a tax system of this type penalized many of the key attributes characterizing HGFs. Distortions of such magnitudes most certainly had a negative effect on the way the actors with different but complementary competencies can cooperate, thereby harming the capability of generating rapidly growing firms, in particular entrepreneurs, venture capitalists, actors in secondary markets and HGFs in their infancy are likely to be negatively affected.

\section{[Table 2]}

A series of tax reforms in Sweden from 1985 until 1994 entailed a substantial 'leveling of the playing field' for different types of owners and sources of finance. The tax changes of 1993-94, primarily the abolishment of wealth tax on unlisted stocks and on dividends at the investor level, and the lowering of capital gains taxation to 12.5 per cent, brought about a dramatic leveling of taxation for different owners and different means of finance compared to the situation in 1980. Taxation on financing by owner equity, regardless of whether it takes the form of a new issue of shares or of earnings plowed back into the firm, became largely the same for households as for other

\footnotetext{
${ }^{36}$ Tax-exempt institutions by definition pay no tax on interest receipts, dividends or capital gains. This category includes charities, scientific and cultural foundations, foundations for employee recreation set up by companies, pension funds for supplementary occupational pension schemes, and the National Pension Fund.
} 
categories of ownership. ${ }^{37}$ This should have a positive effect on the generation and growth of HGF and on structural transformation.

\subsection{Symmetry in the tax treatment of business profits and losses}

It has been argued that governments can provide insurance for business owners by taking part of profits in good times and offsetting losses in bad times (Domar and Musgrave, 1944; Sinn, 1996). If individuals are risk averse, such insurance encourages the risk-taking central to all entrepreneurial activity.

A number of arguments have been put forward to counter this proposition. For instance, it is not valid under progressive taxation and, under most tax codes, that losses be offset against future profits only. It could well be that misdirected forms of insurance only serve to encourage new business ventures among those who are not Schumpeterian entrepreneurs (de Meza, 2002).

In this respect there are also large differences across countries. For instance, Cullen and Gordon (2006) show that the asymmetry in the tax treatment of business profits and losses is greater in Sweden than in the USA ${ }^{38}$ In the USA, the asymmetry actually runs the other way in some cases. Cullen and Gordon (2006, p. 17) write: 'For individuals in the top bracket, risk taking in start-up firms is heavily subsidized in the U.S., but tax penalized in Sweden.' This is due to the fact that in the United States business losses can in certain cases be offset against tax reductions based on the progressive labor tax schedule.

The usual tax asymmetry discourages risk-taking activities even for risk-neutral owners. Since startup activities are often risky, this effect is stronger for new firms than for incumbents. This difference is aggravated to the extent that small firms have more volatile profit streams and fewer opportunities to apply losses in some units to reduce taxes on the gains accruing to other units. For closely held firms, the disincentive to pursue risky activities is even stronger insofar as risk-averse owners have much of their wealth tied up in the firm. As regards the previously reported evidence that HGFs tend

\footnotetext{
${ }^{37}$ These rules were only in place for one year, and the differential across owner categories and sources of finance increased again in 1995 when taxation of dividends at the investor level was reintroduced and the capital gains tax was raised to 30 percent.

${ }^{38}$ Asymmetry refers to a situation whereby the effective tax rate on business profits is greater than the fraction of business losses shared by the government through the tax system.
} 
to be young, it is conceivable that such a policy has negative effects on entrepreneurial activities in general and HGFs in particular.

\subsection{Taxation of savings}

Given the level of wealth or national savings, the composition of national savings is not neutral in its impact on entrepreneurship and small business development. The manner in which savings are channeled to various investment activities influences the type of business organization that can obtain credit. Pension funds, for example, are both relatively risk averse and have difficulties handling smaller individual investments. Therefore, they are less likely to channel funds to entrepreneurs than business angels or venture capital firms. Hence, if the government forces individuals to carry out large part of their savings through a national pension fund system, small business credit availability will suffer relative to an alternative policy and institutional arrangements that allow for greater choice by individuals regarding their savings and investments. But apart from such forced measures the tax system may provide forceful incentives regarding the level and channeling of savings.

A tax system that encourages reliance on savings schemes that escape capital taxation typically restricts the final owner's control of the assets. In doing so, the tax treatment of financial assets and property encourages the accumulation of illiquid assets controlled by large financial institutions rather than assets under the direct control of the final owner. A typical case is pension assets that cannot be withdrawn until a person reaches the retirement age. Personal financial assets with these characteristics cannot be used by the asset holder as working capital neither in an existing owner-operated business nor to start a new owner-operated business. In particular, this would affect entrepreneurs and venture capitalists and, hence, the generation and early growth of HGFs.

If entrepreneurial talent and venture capital competence are unevenly distributed, policies that decrease the likelihood of equity constraints for the entrepreneurially talented and those with talent for being venture capitalists are likely to be beneficial policies. The only efficient means of increasing this likelihood is to pursue economic policies that promote private wealth accumulation across the board, and in ways that do 
not preclude or severely circumscribe that the wealth may be used as equity in entrepreneurial ventures. ${ }^{39}$

\section{Concluding discussion}

We argue that analyses of firm growth in general, and the economic contribution of HGFs in particular, benefit from being evaluated in a broader context of structural transformation. Rapid growth of some firms on one hand requires entry of new firms from which to "recruit" high-growth candidates and on the other hand the contraction and exit of other firms to free up resources for expanding firms. The essence of structural transformation is the reallocation of means of production from certain uses to more productive ones. This way, the economy transforms into new structures: it changes form. Without this dynamic reallocation, the growth of firms would be held back, irrespective of their inherent growth potential. Empirical studies demonstrating HGFs to be of particular importance for driving structural transformation motivates that particular attention is paid to them.

The successful commercialization of innovations - new productive knowledge - by HGFs depends on actors with complementary competencies that work together. The high degree of complexity in production combined with the specifics of human capital makes successful interaction among actors with different key competencies and roles difficult but also highly rewarding when successful. Most (potential) HGFs fail, but the few that succeed account for a substantial part of growth and development in their industries.

Bringing together the specialized, non-transferable competencies of different actors into a well-functioning whole is invariably difficult, even with favorable institutions and public policies, and almost impossible in any other setting. Favorable economic institutions are likely to be of particular importance for the emergence of HGFs, both because of the sensitiveness of competencies to the design of institutions and because of the high social return in terms of growth and job creation.

Our analysis emphasizes the complementary character of institutions. ${ }^{40}$ There is no "quick-fix" that will boost the frequency of HGFs. If policymakers would like to

\footnotetext{
${ }^{39}$ Pelikan (1988) provides forceful arguments supporting this view.
} 
improve conditions for HGFs, our analysis suggests that they need to adopt a broad approach and implement a wide array of complementary institutional reforms. Hence, creating appropriate conditions for growth based on effective constellations of key actors with complementary competencies places great demands on government policies. As is pointed out by many research scholars, picking winners in this chaotic world is virtually impossible and the only winning strategy is 'to let 1000 flowers bloom' (Birch 2006, p. 198). The perpetual search by economic actors for profits that exceed the riskadjusted rate of return available for passive investors leads to a situation in which entrepreneurship, talent and ownership skills are channeled to the most promising areas and supplied in the best possible quantities. This increases the probability that new business opportunities will be developed and exploited to their full potential. This process creates the organizational and structural capital that is an indispensable component in all successful enterprises. The potential entrepreneur can always refrain from developing and using his/her skills and remain an employee with a fixed salary; the venture capitalist can choose to remain passive instead of supplementing his/her financial investment by supplying management skills, and so on.

Our analysis is confined to highly developed countries with basic institutions, such as secure property rights and the rule of law, in place. We have identified three bundles of institutions which are likely to be particularly important for the prevalence of HGFs and for rapid structural transformation: Labor market regulations, the tax system and the degree of free enterprising (the right for private entrepreneurs to establish and provide goods and services with a profit).

Labor market regulations can be expected to influence incentives for potential HGFs and existing HGFs, by restricting the freedom of contracting and thereby curtailing the possible combinations of factors of production. The need for experimentation in order to find more efficient factor combinations is likely to be larger in new firms and industries in general, and in current and potential HGFs in particular.

The most important channel by which labor market institutions affect HGFs is by hampering the supply of skilled workers to firms undergoing expansion and/or change.

\footnotetext{
40 The same conclusion is made by researchers in different fields of economic research. For instance, Orszag and Snower's (1998) study of the complementarity of different policies in the area of unemployment provides an interesting parallel, showing how the effectiveness of one policy depends on the implementation of other policies.
} 
Given the large worker flows required in a dynamic economy, it will be harder to recruit workers with the competencies needed: The opportunity cost of leaving a tenured position goes up for the employees, the fixed cost of hiring goes up when a bad recruitment becomes more costly to reverse; there may be threshold effects that make firms hesitant to expand beyond a certain size, and a great deal of entrepreneurial effort may need to be expended on evasive rather than directly productive activities.

A fundamental insight from our analysis is that experimentation and selection not only takes place across firms, but also between workers and other key actors (notably entrepreneurs) whose productivity is only revealed while working. If temporary contracts are used systematically in order to circumvent regulations tied to permanent employment, industries and business ideas that depend on high-skilled labor and on-thejob learning are disadvantaged. Legal and institutional hurdles that prevent firms from laying off workers that underperform, discourage potential HGFs from expanding. Depending on how labor markets are regulated and how these regulations interact with the social insurance system, the opportunity cost of becoming self-employed is affected. When social security benefits are closely tied to tenured positions and the employee has tenure at a low-risk employer the opportunity cost increases heavily. If employees who establish their own business loose part of their social security entitlements, this can be expected to impact negatively on the recruitment of entrepreneurs.

The analysis reveals that tax systems typically contain many asymmetries giving rise to distortions concerning, for instance, ownership and firm age, which is expected to have a negative effect on the way actors with different but complementary competencies can cooperate, and hence on the ability to generate HGFs. Despite recent trends towards tax harmonization within the EU and the OECD, it is clear that there exist innumerable combinations of tax rates and tax provisions giving rise to different blends of ownership structure, financing structure, industry structure, size distribution of firms and employment dynamics across countries.

Even seemingly neutral taxation may give rise to distortions if, for instance, some actors and firms are more likely to be financially constrained, notably small firms. ${ }^{41}$ Such examples are corporate taxation, taxation on savings and taxation on private wealth where small and young firms to a larger extent rely on retained earnings and

\footnotetext{
${ }^{41}$ See, for instance, Beck et al. (2005) and Angelini and Generale (2008).
} 
private equity. In our view, this is an important determinant of cross-country differences in the prevalence of HGFs. Likewise, the regulatory (tax) burden is likely to fall more heavily on small and young firms (and hence on potential HGFs), since the concomitant administrative costs have a large fixed component that is unrelated to the size of the firm. ${ }^{42}$

Of the three categories of institutions we have discussed, monopolization of production poses the greatest obstacle for the creation and joint functioning of actors with complementary competencies which are instrumental in the generation of HGFs. While high taxes and labor market regulations also impinge on the creation of critical competencies and the actions of key actors embodying these competencies, there is often some scope for (costly) tax evasion and circumvention of labor market regulations. Government monopolization of production considerably constrains the evolution of contestable markets, where critical entrepreneurial and venture capitalist competencies can be developed and acquired through learning. De facto prohibition of profit-driven organizations has the same effect. Consequently, there will be no HGFs.

Moreover, the more complicated and the less stable regulations, the more they benefit large incumbent firms, i.e. firms with a low probability of becoming HGFs. Generally, we find distortions introduced by the three bundles of institutions analyzed to disfavor the kind of firms that have been found to be overrepresented among HGFs, namely young, small and service sector firms. The policies may also enforce each other.

To summarize the effects of the institutions on HGFs we characterize institutions that provide a favorable environment for "dynamic capitalism", the experimental process of creative destruction facilitating the joint functioning of agents with different but complementary competencies and HGFs; see Table 3.

[Table 3]

Even in advanced economies, there is a large untapped economic potential which can be unleashed by institutional changes, such as the opening up of closed markets for entrepreneurial competition. This can be expected to have a positive effect on the emergence of the requisite specialized actors and the prevalence of HGFs. The effect would be more pronounced if tax structures and labor market institutions

\footnotetext{
42 This is recognized in a number of countries identifying the regulatory burden itself as an impediment to
} 
simultaneously were adjusted in order to stimulate the emergence of more effective cooperation of the different types of actors, and institutions were made more neutral with respect to firm attributes, type of ownership and source of finance. The two most important conclusions from this analysis are that (i) institutions have far-reaching effects, and (ii) to identify these effects on HGFs, the respective institutions have to be studied in depth. The Devil is in the details!

It is appropriate to end with a word of caution and point out that the relationship between institutions, entrepreneurship and other productive competencies, and growth is currently only partly understood. Much more research in this respect is called for to gain a fuller understanding both qualitatively — which are the key institutions and how do they interact with one another - and quantitatively. To be able to quantify the effect of changes in a specific institution such as a key tax rate or labor security mandates, empirical research requires heterogeneity of institutions like in cross-country comparison or instances of "clean" changes in a particular institution. Here, a great deal can be learnt from labor economics, where considerable knowledge has been gained from the study of quasi experiments, often using instrumental variable techniques; see Angrist and Krueger (2001). There are many possible instances that could be utilized. Let us just mention two: (i) the different strategies by universities vis-à-vis the involvement of their faculty in the commercialization of research (Siegel et al. 2003); (ii) the lessening of the employee protection legislation in Sweden in 2001 for firms with fewer than 10 employees (Lindbeck et al. 2006).

Furthermore, institutions do not come out of thin air; they emerge and develop in a specific context. ${ }^{43}$ In propitious circumstances informal and formal institutions evolve in ways that encourage economic growth by facilitating the entrepreneurial exploitation of economically valuable knowledge. However, this is by no means guaranteed. History is replete with examples where the evolution of institutions supporting dynamic capitalism has been severely hampered and even totally blocked.

\footnotetext{
economic development, in particular for young and small firms (see, e.g. European Commission, 2007).

${ }^{43}$ The literature trying to explain institutional change or the lack thereof is currently expanding fairly rapidly. See, e.g. Kasper and Streit (1998, Ch. 12), Zweynert (2009) and Boettke and Coyne (2009).
} 


\section{References}

Abowd, John M. and Francis Kramarz (1999), 'The Analysis of Labor Markets Using Matched Employer-Employee Data', in Orley Ashenfelter and David Card (eds), Handbook of Labor Economics, Vol. 3, Amsterdam: Elsevier, pp. 2629-2710.

Acemoglu, Daron, Simon Johnson and James A. Robinson (2005), 'Institutions as the Fundamental Cause of Long-run Growth', in Philippe Aghion and Steven Durlauf, (eds), Handbook of Economic Growth, Amsterdam: Elsevier, pp. 385-472.

Acs, Zoltan J. (2010), 'High Impact New Businesses', in Michael Fritsch (ed), Handbook of Research on Entrepreneurship and Regional Development, Cheltenham, UK and Northampton, MA: Edward Elgar, forthcoming..

Acs, Zoltan J. and Pamela Mueller (2008), 'Employment Effects of Business Dynamics: Mice, Gazelles and Elephants', Small Business Economics, 30 (1), 85-100.

Acs, Zoltan J., Parsons,William and Tracy, Spencer (2008), 'High Impact Firms: Gazelles Revisited ', An Office of Advocacy Working Paper, U.S. Small Business Administration.

Adema, Willem (2001), 'Net Social Expenditure: $2^{\text {nd }}$ Edition', OECD Labor Market and Social Policy Occasional Papers, No. 52, Paris: OECD.

Adema, Willem and Maxime Ladaique (2005), 'Net Social Expenditure, 2005 Edition: More Comprehensive Measures of Social Support', OECD Social, Employment and Migration Working Papers, No. 29, Paris: OECD.

Agell, Jonas, Peter Englund and Jan Södersten (1998), Incentives and Redistribution in the Welfare State-The Swedish Tax Reform, London: Macmillan.

Andersen, Torben M. (2005), 'The Danish Labor Market-from Excess to Shortage', in Martin Werding (ed), Structural Unemployment in Western Europe: Reasons and Remedies, Cambridge MA: MIT Press.

Andersen, Torben M. (2008) 'The Scandinavian Model—Prospects and Challenges', International Tax and Public Finance, 15 (1), 45-66.

Angelini, Paolo and Andrea Generale (2008), 'On the Evolution of Firm Size Distributions', American Economic Review, 98 (1), 426-438.

Angrist, Joshua D. and Alan B. Krueger (2001), 'Instrumental Variables and the Search for Identification: From Supply and Demand to Natural Experiments', Journal of Economic Perspectives, 15 (4), 6985.

Arai, Mahmood and Fredrik Heyman (2004), 'Temporary Contracts and the Dynamics of Job Turnover', Economics Bulletin, 10 (4), 1-6.

Audretsch, David B. (1995), Innovation and Industry Evolution, Cambridge, MA: MIT Press.

Audretsch, David B. (2002), 'The Dynamic Role of Small Firms: Evidence from the U.S.', Small Business Economics, 18 (1), 13-40.

Audretsch, David B. and Maryann P. Feldman, (2003), 'Small-Firm Strategic Research Partnerships: The Case of Biotechnology', Technology Analysis \& Strategic Management, 15 (2), 273-288.

Audretsch, David B. and Michael Fritsch, (2002), 'Growth Regimes over Time and Space', Regional Studies, 36 (2), 113-124.

Axelsson, Sten (2006), 'Entreprenörer från sekelskifte till sekelskifte—kan företag växa i Sverige?', in Dan Johansson and Nils Karlson (eds), Svensk utvecklingskraft, Stockholm: Ratio, pp. 57-97.

Bartelsman, Eric J., John Haltiwanger and Stefano Scarpetta (2004), 'Microeconomic Evidence of Creative Destruction in Industrial and Developing Countries', World Bank, Policy Research Working Paper Series No. 3464.

Bartelsman, Eric, Stefano Scarpetta and Fabiano Schivardi (2005), 'Comparative Analysis of Firm Demographics and Survival: Evidence from Micro-level Sources in OECD Countries', Industrial and Corporate Change, 14 (3), 365-391. 
Baumol, William J. (1990), 'Entrepreneurship: Productive, Unproductive, and Destructive', Journal of Political Economy, 98(5), 893-921.

Baumol, William J. (2004), 'Entrepreneurial Enterprises, Large Established Firms and Other Components of the Free-Market Growth Machine’, Small Business Economics, 23 (1), 9-21.

Beck, Thorsten, Asli Demirgüc-Kunt and Vojislav Maksimovic (2005), 'Financial and Legal Constraints to Growth: Does Firms Size Matter?', Journal of Finance, 60 (1), 137-177.

Bhidé, Amar (2008), The Venturesome Economy: How Innovation Sustains Prosperity in a More Connected World, Princeton: Princeton University Press.

Birch, David L. (1979), The Job Generation Process. MIT Program on Neighborhood and Regional Change, Massachusetts Institute of Technology, Cambridge, MA.

Birch, David L. (2006), 'What Have We Learned?', Foundations \& Trends in Entrepreneurship, 2 (3), 197-202.

Birch, David L. and James Medoff (1994), 'Gazelles', in Lewis C. Solmon and Alec R. Levenson, (eds), Labor Markets, Employment Policy and Job Creation, Boulder, CO and London: Westview Press, pp. 159-167.

Blanchflower, David G. and Richard B. Freeman (1992), 'Going Different Ways: Unionism in the US and other OECD Countries', Industrial Relations, 31 (Winter), 156-179.

Blau, Francine D. and Lawrence M. Kahn (1996), 'International Differences in Male Wage Inequality: Institutions versus Market Forces', Journal of Political Economy, 104 (4), 791-837.

Blau, Francine D. and Lawrence M. Kahn (1999), 'Institutions in the Labor Market', in Orley Ashenfelter and David Card (eds), Handbook of Labor Economics, Vol. 3, Amsterdam: Elsevier, pp. 1399-1461.

Boettke, Peter J. and Christopher J. Coyne (2009), 'Context Matters: Institutions and Entrepreneurship', Foundations and Trends in Entrepreneurship, 5 (3), 135-209.

Brown, Charles and James Medoff (1989), 'The Employer Size Wage Effect', Journal of Political Economy, 97 (5), 1027-1059.

Brown, Clair, John Haltiwanger and Julia Lane (2006), Economic Turbulence: Is a Volatile Economy Good for America? Chicago, IL: University of Chicago Press.

Caballero, Ricardo (2007), Specificity and the Macroeconomics of Restructuring. Cambridge, MA: MIT Press.

Cullen, Julie Berry and Roger H. Gordon (2006), 'How Do Taxes Affect Entrepreneurial Activity? A Comparison of U.S. and Swedish Law', Mimeo. UC San Diego.

Davis, Steven J. and John Haltiwanger (1996), 'Employer Size and the Wage Structure in U.S. Manufacturing', Annales d'Économie et de Statistique, 41/42, 323-367.

Davis, Steven J. and John Haltiwanger (1999), 'Gross Job Flows', in Orley Ashenfelter and David Card (eds), Handbook of Labor Economics, Vol. 3, Amsterdam: Elsevier, pp. 2771-2805.

Davis, Steven J. and Magnus Henrekson (1997), 'Industrial Policy, Employer Size and Economic Performance in Sweden', in Richard B. Freeman, Birgitta Swedenborg and Robert Topel (eds), The Welfare State in Transition: Reforming the Swedish Model, Chicago, IL: Chicago University Press, pp. 353-397.

Davis, Steven J. and Magnus Henrekson (2005), 'Tax Effects on Work Activity, Industry Mix and Shadow Economy Size: Evidence from Rich-Country Comparisons', in Ramón Gómez-Salvador et al. (eds), Labour Supply and the Incentives to Work in Europe, Cheltenham, UK and Northampton, MA: Edward Elgar, pp. 44-104.

de Meza, David (2002), 'Overlending?', Economic Journal, 112 (477), F17-F31.

Dew-Becker, Ian and Robert J. Gordon (2008), 'The Role of Labor Market Changes in the Slowdown in European Productivity Growth’, NBER Working Paper No. 131840.

Domar, Evsey D. and Richard A. Musgrave (1944), 'Proportional Income Taxation and Risk-Taking', Quarterly Journal of Economics, 58 (3), 388-422. 
Eliasson, Gunnar and Åsa Eliasson (1996), 'The Biotechnical Competence Bloc', Revue d'Economie Industrielle, 78 (1), 7-26.

Eliasson, Gunnar and Kurt Vikersjö (1999), 'Recruiting in a European Company', Vocational Training, 12 (1), 14-19.

European Commission (2007), 'Models to Reduce the Disproportionate Regulatory Burden on SMEs', Enterprise and Industry Directorate-General, Report of the Expert Group, Brussels: European Commission.

Fenn, George, Nellie Liang and Stephen Prowse (1995), 'The Economics of the Private Equity Market', Washington, D.C.: Board of Governors of the Federal Reserve System.

Flamholtz, Eric G. (1986), Managing the Transition from an Entrepreneurship to a Professionally Managed Firm, San Francisco: Jossey-Bass.

Fogel, Kathy, Randall K. Morck and Bernard Yeung, (2008), 'Big Business Stability and Economic Growth: Is What's Good for General Motors Good for America?', Journal of Financial Economics, 89 (1), 83-108.

Fogel, Robert W. (1999), 'Catching up with the Economy', American Economic Review, 89 (1), 1-21.

Freeman, Richard B. (1998), 'War of the Models: Which Labour Market Institutions for the 21st Century', Labour Economics, 5 (1), 1-24.

Freeman, Richard B. and Ronald Schettkat (2005) 'Marketization of Household Production and the EUUS Gap in Work', Economic Policy, 20 (41), 6-50.

Fritsch, Michael (2004), 'Entrepreneurship, Entry and Performance of New Business Compared in Two Growth Regimes: East and West Germany', Journal of Evolutionary Economics, 14 (5), 525-542.

Fritsch, Michael and Pamela Mueller (2004), 'Effects of New Business Formation on Regional Development over Time', Regional Studies, 38 (3), 961-975.

Fritsch, Michael and Pamela Mueller (2006), 'The Evolution of Regional Entrepreneurship and Growth Regimes', in Michael Fritsch and Jürgen Schmude (eds), Entrepreneurship in the Region, New York: Springer, pp. 225-244.

Fritsch, Michael and Florian Noseleit (2009), 'Investigating the Anatomy of the Employment Effects of New Business Formation', Jena Economic Research Paper 2009-001.

Fukao, Mitsuhiro and Masaharu Hanazaki (1987), 'Internationalization of Financial Markets and the Allocation of Capital', OECD Economic Studies, No. 8, 35-92.

Galbraith, John Kenneth (1956), American Capitalism: The Concept of Countervailing Power, Boston: Houghton Mifflin.

Galbraith, John Kenneth (1967), The New Industrial State, London: Hamish Hamilton.

Garen, John E. (1985), 'Worker Heterogeneity, Job Screening, and Firm Size’, Journal of Political Economy, 93 (4), 715-739.

Gompers, Paul A. and Josh Lerner (2001), The Money of Invention: How Venture Capital Creates New Wealth, Cambridge, MA: Harvard University Press.

Halabisky, David, Erwin Dreessen and Chris Parsley (2006), 'Growth in Firms in Canada, 1985-1999', Journal of Small Business and Entrepreneurship, 19 (3), 255-268.

Hall, Peter and David Soskice (eds), (2001), Varieties of Capitalism: The Institutional Foundation of Comparative Advantage. Oxford: Oxford University Press.

Haltiwanger, John and C. J. Krizan (1999), 'Small Business and Job Creation in the United States: The Role of New and Young Businesses', in Zoltan J. Acs (ed), Are Small Firms Important? Their Role and Impact, Boston, MA, Dordrecht, NL and London, UK: Kluwer Academic Publishers, pp. 7997.

Hart, Oliver, Andrei Schleifer and Robert W. Vishny (1997), 'The Proper Scope of Government: Theory and an Application to Prisons', Quarterly Journal of Economics, 112 (4), 1127-1161.

Hayek, Friedrich (1937), 'Economics and Knowledge', Economica, 4 (1), 33-54. 
Hayek, Friedrich A. (1945), 'The Use of Knowledge in Society', American Economic Review, 35 (4), 2130.

Hayek, Friedrich A. (1978), 'Competition as a Discovery Procedure', in Chiaki Nishiyami and Kurt Leube (eds), The Essence of Hayek, Stanford: Hoover Institution Press, pp. 361-381.

Henrekson, Magnus and Dan Johansson (2010), 'Gazelles as Job Contributors-A Survey and Interpretation of the Evidence', Small Business Economics, in press.

Hibbs, Douglas A. and Håkan Locking (2000), 'Wage Dispersion and Productive Efficiency: Evidence for Sweden', Journal of Labor of Economics, 18 (4), 755-782.

Jansson, Jan Owen (2006), The Economics of Services. Development and Policy, Cheltenham, UK and Northampton, MA: Edward Elgar.

Johansson, Dan (2005), 'The Turnover of Firms and Industry Growth', Small Business Economics, 24 (5), 487-495.

Johansson, Dan (2010), 'The Theory of the Experimentally Organized Economy and Competence Blocs: An Introduction', Journal of Evolutionary Economics, 20 (2), 185-201.

Jones, Charles I. (2001), 'Was an Industrial Revolution Inevitable? Economic Growth over the Very Long Run', Advances in Macroeconomics, 1 (2), 1028-1048.

Kasper, Wolfgang and Manfred E. Streit (1998), Institutional Economics. Cheltenham, UK and Northampton, MA: Edward Elgar.

King, Mervyn A. and Don Fullerton (1984), The Taxation of Income from Capital: A Comparative Study of the United States, the United Kingdom, Sweden and West Germany, Chicago: University of Chicago Press.

Kirchhoff, Bruce A. (1994), Entrepreneurship and Dynamic Capitalism, Westport, CT: Praeger.

Kirchhoff, Bruce A. and Patricia G. Greene (1998), 'Understanding the Theoretical and Empirical Content of Critiques of U.S. Job Creation Research', Small Business Economics, 10 (2), 153-169.

Klepper, Steven and Kenneth L. Simons (2005), 'Industry Shakeouts and Technological Change', International Journal of Industrial Organization, 23 (1-2), 23-43.

Kleven Jacobsen, H., Wolfram F. Richter and Peter Birch Sørensen (2000), 'Optimal Taxation with Household Production', Oxford Economic Papers, 52 (3), 584-594.

Kremer, Michael (1993), 'The O-Ring Theory of Economic Development', Quarterly Journal of Economics, 108 (3), 551-576.

Laffont, Jean-Jacques and Jean Tirole (1993), A Theory of Incentives in Regulation and Procurement, Cambridge, MA: MIT Press.

Landström, Hans (2007), Handbook of Research on Venture Capital, Cheltenham, UK and Northampton, MA: Edward Elgar.

Lazerson, Mark H. and Gianni Lorenzoni (1999), 'The Firms That Feed Industrial Districts: A Return to the Italian Source', Industrial and Corporate Change, 8 (2), 235-266.

Le Grand, Julian (2007), The Other Invisible Hand: Delivering Public Services through Choice and Competition, Princeton and Oxford: Princeton University Press.

Lerner, Joshua and Robert, P. Merges (1998), 'The Control of Technology Alliances: An Empirical Analysis of the Biotechnology Industry', Journal of Industrial Economics, 46 (2), 125-156.

Lindbeck, Assar, Sten Nyberg and Jörgen W. Weibull (1999), 'Social Norms and Economic Incentives in the Welfare State', Quarterly Journal of Economics, 114 (1), 1-35.

Lindbeck, Assar, Mårten Palme and Mats Persson (2006), 'Job Security and Work Absence: Evidence from a Natural Experiment', IFN Working Paper No. 660, Research Institute of Industrial Economics, Stockholm.

Lindkvist, Hans (1990), Kapitalemigration, Doctoral Dissertation, Stockholm School of Economics.

Lucas, Robert E. (1978), 'On the Size Distribution of Business Firms', Bell Journal of Economics, 9 (2), 508-523. 
Maddison, Angus (2009), http://www.ggdc.net/Maddison/Historical_Statistics/vertical-file_03-2009.xls (accessed 23 September 2009).

Misher, Norman (1984), 'Tax Consequences of Exercising An Incentive Stock Option with Stock of the Granting Corporation', The Tax Executive, July, 357-363.

Mokyr, Joel (1990), The Lever of Riches: Technological Creativity and Economic Progress, Oxford: Oxford University Press.

North, Douglass C. (1990), Institutions, Institutional Change, and Economic Performance, Cambridge: Cambridge University Press.

North, Douglass C. and Robert Thomas (1973), The Rise of the Western World: A New Economic History, Cambridge: Cambridge University Press.

OECD (2005), Modernising Government: The Way Forward, Paris: OECD.

Oi, Walter and Todd L. Idson (1999), 'Firm Size and Wages' in Orley Ashenfelter and David Card (eds), Handbook of Labor Economics, Vol. 3, Amsterdam: Elsevier, pp. 2165-2214.

Orszag, Mike and Dennis J. Snower (1998), 'Anatomy of Policy Complementarities', Swedish Economic Policy Review, 5 (2), 303-343.

Parker, Simon C., David J. Storey and Arjen van Witteloostuijn (2010), 'What Happens to Gazelles?', Small Business Economics, forthcoming.

Pelikan, Pavel (1988), 'Can the Imperfect Innovation Systems of Capitalism be Outperformed', in Technical Change and Economic Theory, edited and compiled by the Maastricht Economic Research Institute on Innovation and Technology, New York: Columbia University Press, pp. 370398.

Pelikan, Pavel (1993), 'Ownership of Firms and Efficiency: The Competence Argument', Constitutional Political Economy, 4 (3), 349-392.

Phelps, Edmund S. (2007), 'Macroeconomics for a Modern Economy', American Economic Review, 97 (3), 543-561.

Piggott, John and John Whalley (2001), 'VAT Base Broadening, Self Supply, and the Informal Sector', American Economic Review, 91 (4), 1084-1094.

Prowse, Stephen (1998), 'The Economics of the Private Equity Market', Federal Reserve Bank of Dallas, Economic Review, $3^{\text {rd }}$ Quarter, 21-34.

Robson, Martin T. (2003), 'Does Stricter Employment Protection Legislation Promote Selfemployment?', Small Business Economics, 21 (3), 309-319.

Rogerson, Richard (2006), 'Understanding Differences in Hours Worked', Review of Economic Dynamics, 9 (3), 365-409.

Rosen, Harvey S. (2005), 'Entrepreneurship and Taxation: Empirical Evidence', in Vesa Kanniainen and Christian Keuschnigg (eds), Venture Capital, Entrepreneurship and Public Policy, Cambridge, MA: MIT Press, pp. 251-279.

Rosenberg, Nathan and Luther E. Birdzell Jr. (1986), How the West Grew Rich: The Economic Transformation of the Industrial World, London: Tauris.

Saxenian, AnnaLee (1996), Regional Advantage. Culture and Competition in Silicon Valley and Route 128, Cambridge, MA: Harvard University Press.

Shane, Scott A. (2008), The Illusions of Entrepreneurship, New Haven, CT: Yale University Press.

Shleifer, Andrei (1998), 'State versus Private Ownership', Journal of Economic Perspectives, 12 (4), 133-150.

Schnabel, Claus, Susanne Kohaut and Udo Brixy (2008), 'Employment, Stability of Entrants in Newly Founded Firms: A Matching Approach Using Linked Employer-Employee Data from Germany’, Discussion Paper No. 9, Institut für Arbeitsmarkt- und Berufsforschung, Nürnberg. 
Schreyer, Paul (2000), 'High-growth Firms and Employment', OECD Science, Technology and Industry Working Papers, 2000/3, Paris.

Schumpeter, Joseph A. (1934/[1911]), The Theory of Economic Development, New Brunswick and London: Transaction Publishers.

Schumpeter, Joseph A. (1942), Capitalism, Socialism and Democracy, New York and London: Harper \& Brothers.

Siegel, Donald S, David Waldman and Albert N. Link (2003), 'Assessing the Impact of Organizational Practices on the Relative Productivity of University Technology Transfer Offices: An Exploratory Study', Research Policy, 32 (1), 27-48.

Sinn, Hans-Werner (1996), 'Social Insurance, Incentives and Risk-Taking', International Tax and Public Finance, 3 (3), 259-280.

Skedinger, Per (2010), Employment Protection Legislation: Evolution, Effects, Winners and Losers, Cheltenham, UK, and Northampton, MA: Edward Elgar.

Smith, Adam (1776), The Wealth of Nations, Chicago: University of Chicago Press.

SOU 2002:31, Vinst för vården (Profit in the Health Care Sector), Stockholm: Ministry of Social Affairs.

Södersten, Jan (1984), 'Sweden', in Mervyn A. King and Don Fullerton (eds), The Taxation of Income from Capital: A Comparative Study of the United States, the United Kingdom, Sweden and West Germany, Chicago: University of Chicago Press, pp. 87-148.

Storey, David J. (1994), Understanding the Small Business Sector, London: Routledge.

Torrini, Riccardo (2005), 'Cross-country Differences in Self-employment Rates: The Role of Institutions', Labour Economics, 12 (4), 661-683.

van Praag, C. Mirjam and Peter H. Versloot (2007), 'What Is the Value of Entrepreneurship? A Review of Recent Research', Small Business Economics, 29 (4), 351-382.

van Praag, C. Mirjam and Peter H. Versloot (2008), 'The Economic Benefits and Costs of Entrepreneurship: A Review of the Research', Foundations and Trends in Entrepreneurship, 4 (2), 65-154.

von Hippel, Eric (2007), 'Horizontal Innovation Networks—-by and for Users', Industrial and Corporate Change, 16 (2), 293-315.

Williamson, Claudia R. (2009), 'Informal Institutions Rule: Institutional Arrangements and Economic Performance', Public Choice, 139 (3-4), 371-387.

Winston, Clifford (1998), 'U.S. Industry Adjustment to Economic Regulation', Journal of Economic Perspectives, 12 (3), 89-110.

Winter, Sidney G. (1984), 'Schumpeterian Competition in Alternative Technological Regimes', Journal of Economic Behavior and Organization, 5 (3), 287-320.

Wright, Mike, (2007), 'Private Equity and Management Buy-outs', in Hans Landström (ed), Handbook of Research on Venture Capital, Cheltenham, UK and Northampton, MA: Edward Elgar, pp. 281-314.

Zider, Bob (1998), 'How Venture Capital Works', Harvard Business Review, November-December, 131-139.

Zweynert, Joachim (2009), 'Interests versus Culture in the Theory of Institutional Change', Journal of Institutional Change, 5 (3), 339-360. 
Figure 1 Gross Domestic Product per capita for all history of mankind

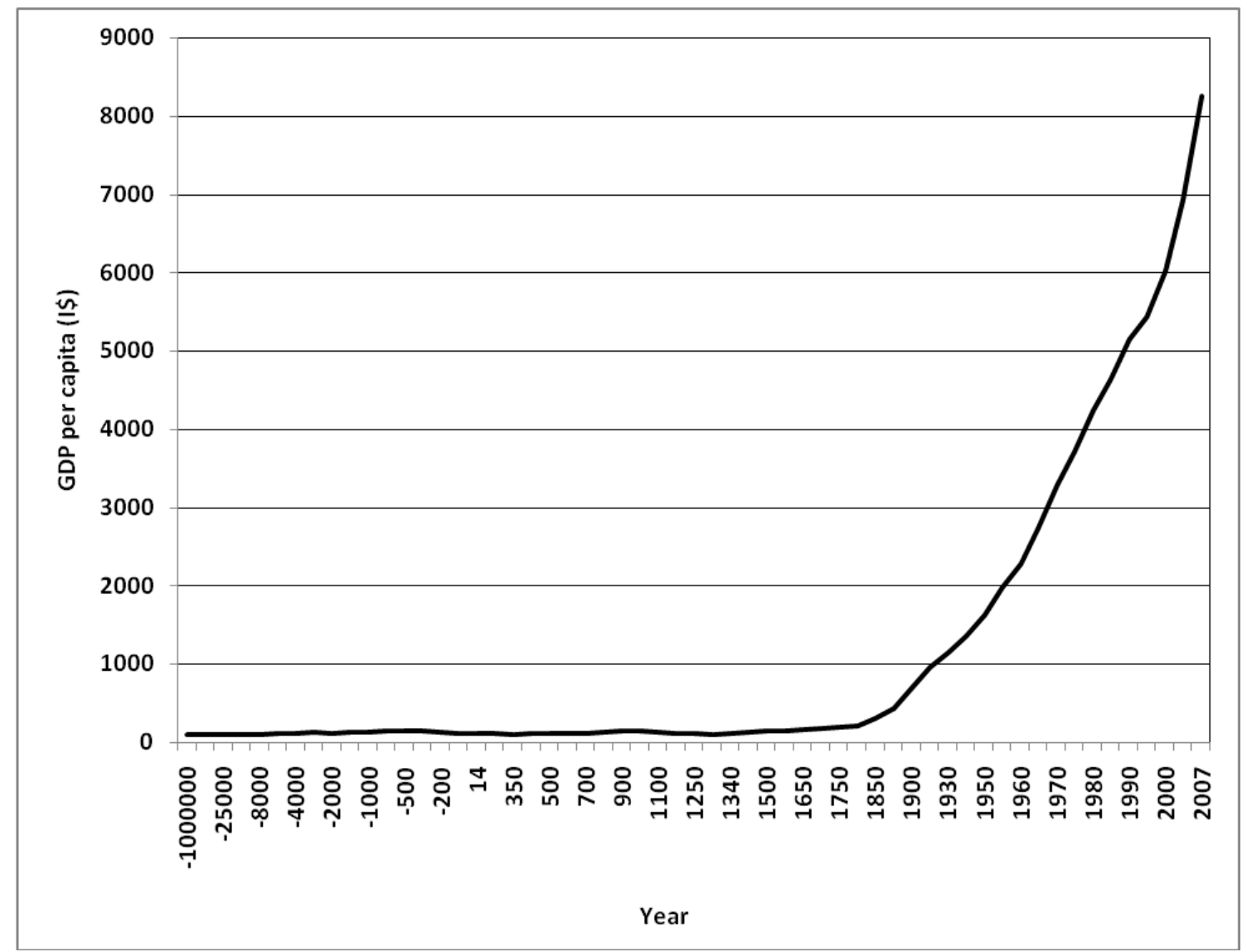

Source: De Long/Kremer data from -1000000 to 1985 (extension of Maddison's estimates; Kremer 1993), Maddison data from 1985 to 2005 (GDP per capita, 1990 International Dollars; Maddison 2009), World Bank data for 2007 (GDP per capita, US\$) from http://web.worldbank.org/WBSITE/EXTERNAL/DATASTATISTICS/0,,menuPK:232599 pagePK:6 4133170 piPK:64133498 theSitePK:239419,00.html. 
Figure 2 The roles and interaction of different actors fostering HGFs.

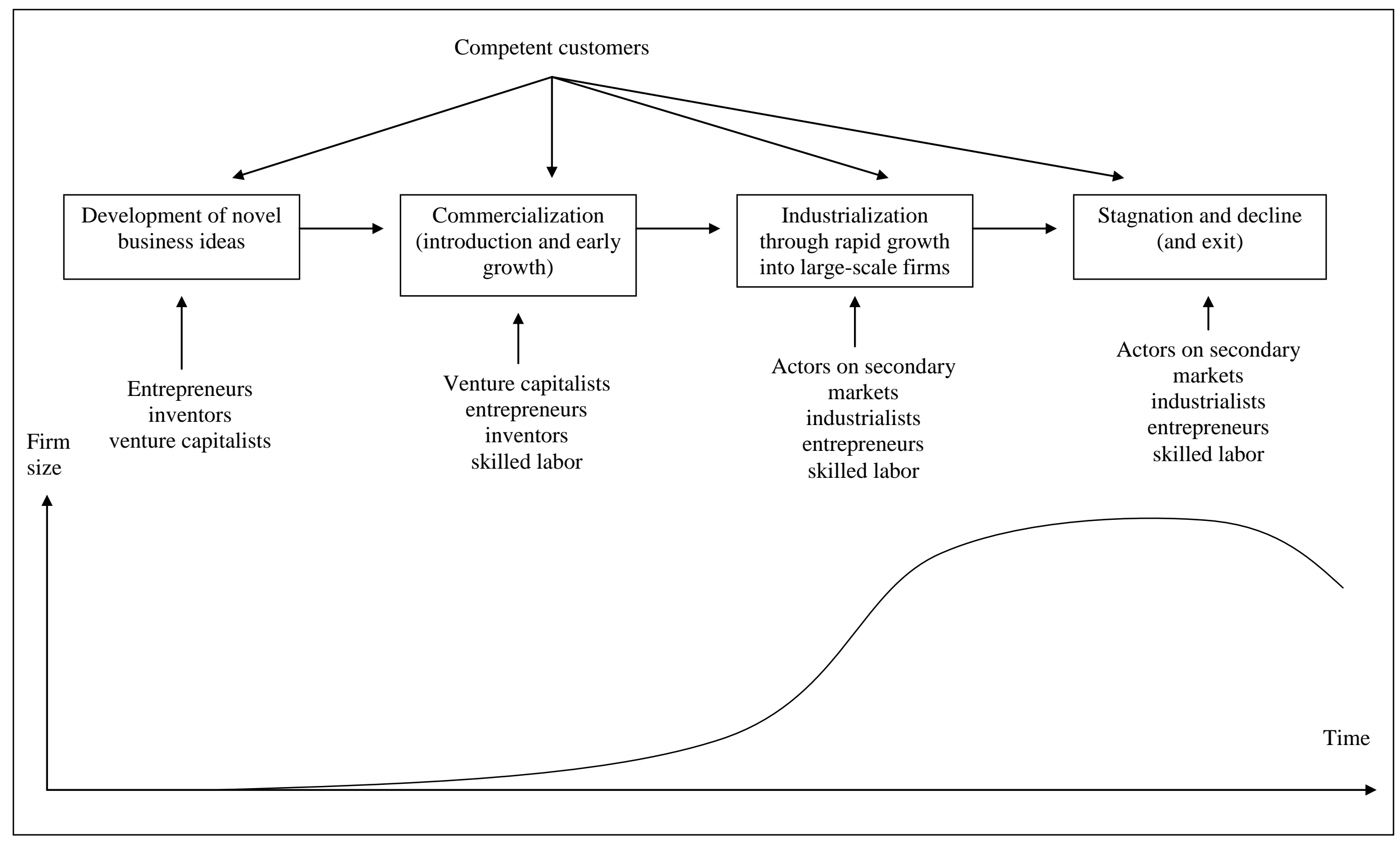


Table 1 Regulations, the prevalence of HGFs and structural transformation.

\begin{tabular}{|c|c|c|}
\hline & Private production & Monopolized production \\
\hline \multirow[t]{2}{*}{ Private financing } & $\begin{array}{l}\text { Entrepreneurs - Yes } \\
\text { Inventors - Yes } \\
\text { Industrialists - Yes } \\
\text { Skilled labor - Yes } \\
\text { Business angels - Yes } \\
\text { Venture capitalists - Yes } \\
\text { Actors in secondary markets - Yes } \\
\text { Competent customers - Yes }\end{array}$ & $\begin{array}{l}\text { Entrepreneurs - No } \\
\text { Inventors- Limited } \\
\text { Industrialists - No } \\
\text { Skilled labor - Limited } \\
\text { Business angels - No } \\
\text { Venture capitalists - No } \\
\text { Actors in secondary markets - No } \\
\text { Competent customers - Limited }\end{array}$ \\
\hline & $\begin{array}{l}\text { All actors present, prevalence of HGFs and } \\
\text { fast structural transformation }\end{array}$ & $\begin{array}{l}\text { Several key competencies missing, } \\
\text { imperfectly replaced by government, } \\
\text { no HGFs and slow structural } \\
\text { transformation }\end{array}$ \\
\hline \multirow[t]{2}{*}{$\begin{array}{l}\text { Public } \\
\text { financing }\end{array}$} & $\begin{array}{l}\text { Entrepreneurs - Possible } \\
\text { Inventors - Possible } \\
\text { Industrialists - Possible } \\
\text { Skilled labor - Yes } \\
\text { Business angels - Possible } \\
\text { Venture capitalists - Possible } \\
\text { Actors in secondary markets - Possible } \\
\text { Competent customers - Limited }\end{array}$ & $\begin{array}{l}\text { Entrepreneurs - No } \\
\text { Inventors-Limited } \\
\text { Industrialists- No } \\
\text { Skilled labor - Limited } \\
\text { Business angels - No } \\
\text { Venture capitalists - No } \\
\text { Actors in secondary markets - No } \\
\text { Competent customers - No }\end{array}$ \\
\hline & $\begin{array}{l}\text { Potential impediments to presence of all } \\
\text { actors, HGFs and to structural } \\
\text { transformation, depending on institutional } \\
\text { climate }\end{array}$ & $\begin{array}{l}\text { Most key competencies missing, } \\
\text { imperfectly replaced by government, } \\
\text { no HGFs and slow structural } \\
\text { transformation }\end{array}$ \\
\hline
\end{tabular}


Table 2 Effective marginal tax rates for different combinations of owners and sources of finance in Sweden, 1980 and 1994 (real pre-tax rate of return $=10 \%$ ).

\begin{tabular}{lrrr}
\hline & Debt & $\begin{array}{r}\text { New share } \\
\text { issues }\end{array}$ & $\begin{array}{r}\text { Retained } \\
\text { earnings }\end{array}$ \\
\hline $\mathbf{1 9 8 0}$ & & & \\
Households & 58.2 & 136.6 & 51.9 \\
Tax exempt institutions & -83.4 & -11.6 & 11.2 \\
Insurance companies & -54.9 & 38.4 & 28.7 \\
$\mathbf{1 9 9 4}$ & & & \\
Households & & & \\
Tax exempt institutions & $32.0 / 27.0 \dagger$ & $28.3 / 18.3 \dagger$ & $36.5 / 26.5 \dagger$ \\
Insurance companies & -14.9 & 21.8 & 21.8 \\
\hline
\end{tabular}

Note: $\dagger$ Excluding wealth tax, the wealth tax on unlisted shares was abolished in 1992. All calculations are based on the actual asset composition in manufacturing. The following inflation rates were used: 1980: 9.4\%, 1994: 3\%. The calculations conform to the general framework developed by King and Fullerton (1984). The average holding period is assumed to be 10 years. A negative tax rate implies that the rate of return after tax is greater than before tax. For instance, a tax rate of -83 percent for a debt-financed investment owned by a tax-exempt institution in 1980 tells us that a real rate of return of 10 percent before tax becomes $18.34(10-(-8.34))$ percent after tax, while a real rate of return of 10 percent before tax for a debt-financed investment owned by a household becomes $4.18(10-5.82)$ after tax.

Source: Södersten (1984), and calculations provided directly by Jan Södersten. ${ }^{44}$

${ }^{44}$ Jan Södersten has given permission to reproduce these results. 
Table 3 Institutions favoring dynamic capitalism, the emergence of HGFs and structural transformation.

\begin{tabular}{ll}
\hline Institution & \\
\hline Marginal tax rate & Low \\
$\begin{array}{l}\text { Personal tax on capital income } \\
\text { Personal tax on capital gains }\end{array}$ & Low \\
Tax on stock options & Low \\
Degree of tax neutrality across & Neutrality \\
owner categories & \\
$\begin{array}{l}\text { Degree of neutrality across } \\
\text { sources of finance }\end{array}$ & Neutrality \\
Personal taxation of asset & No, or exemption for equity holdings \\
holdings & \\
Corporate tax rate & Low statutory rate, low effective rate, \\
$\begin{array}{l}\text { Symmetric tax treatment of } \\
\text { profit and losses }\end{array}$ & neutral across types of firms and industries \\
Labor security mandates & Portability of tenure rights \\
Design of pension plans & Fully actuarial \\
Wage-setting arrangements & Decentralized and individualized \\
Production of welfare & Sizeable private production, contestability \\
services/merit goods & \\
Financing of welfare & Government ensures basic high quality \\
services/merit goods & supply, then private financing \\
Profit-driven organizations & Fully allowed \\
Government role in income & Provide flexicurity \\
insurance & \\
\hline
\end{tabular}

